\title{
İstanbul'da Yol Kenarı Parklarda Kullanıcı Alışkanlıklarının İncelenmesi
}

\begin{abstract}
Abdullah DEMIR ${ }^{1}$
ÖZ

İstanbul, yaklaşık 15 milyonluk nüfusu, 2,669 milyonu otomobil olmak üzere 3,875 milyonluk araç parkı ve kontrollü/kontrolsüz park etmenin \%70'i aşan oranda yol kenarlarında olduğu mega bir şehirdir. Bu çalışmada İstanbul'daki yol kenarı otopark kullanıcı davranışlarındaki değişimler, yaklaşık 8 yıllık otopark verilerinden yararlanılarak; saat, gün, ay, mevsim ve yıllara göre analiz edilmiştir. Ayrıca ücret artışının ve kısa süreli ücretsiz park uygulamalarının etkileri de incelenmiştir. Çalışma neticesinde; günde \%20'lik park girişinin saat 09.00 ile 11.00 arasında, en fazla işlemin haftanın orta günü olan Çarşamba'da, en az işlem ve en uzun ortalama park etme süresinin de Pazar gününde meydana geldiği tespit edilmiştir. Ayrıca yıllar geçtikçe araçların otoparkta kalma sürelerinin artış göstererek 2 saate yaklaştığı ve Avrupa yakasında saat 14.00-15.00 arasında doluluk oranının \%86'ya eriştiği de saptanmıştır. Bir diğer önemli incelemede yol kenarı otoparklarda uygulanan 0-15 dakika ücretsiz park seçeneğinin geçici bir süre kaldırılmasıyla; devinimlerde belirgin düşme, tahsilat oranında, her bir işlem başına düşen gelirde, ortalama park etme sürelerinde ise artış olduğu ve 15 dakika ücretsiz park etme hakkının tekrar uygulanmasıyla birlikte tahakkuk-tahsilat oranında belirgin artış olduğu ve bu durumun kullanıcı ödeme alışkanlığını pozitif yönde etkilediği de saptanmıştır. Bunlardan başka mevsim bazlı ortalama park süresi zaman serisiyle incelenmiş ve ulaşım ana planında verilmiş olan otopark ücretlendirme modeli Stata 14 yazılım programı kullanılarak regresyon analiziyle incelenmiş ve tutarsızlığ 1 tespit edilmiştir.
\end{abstract}

Anahtar Kelimeler: Park etme davranışı, yol kenarı otopark, park süresi ve fiyatı, 0-15 dakika ücretsiz park seçeneği.

\section{ABSTRACT}

\section{Investigation of User's Behaviors in Paid On-street Parking in İstanbul}

Istanbul is a megacity with a population of approximately 15 million, motor vehicles of 3.875 million including 2.669 million passenger cars, and on-street parking exceeding 70 percent

1

Not: Bu yaz1

- Yayın Kurulu'na 15.12.2017 günü ulaşmıştır. 04.07.2018 günü yayımlanmak üzere kabul edilmiştir.

- 31 Temmuz 2019 gününe kadar tartışmaya açıktır.

- https://dx.doi.org/10.18400/tekderg.366692

1 Marmara Üniversitesi, Makine Mühendisliği Bölümü, İstanbul - ademir@marmara.edu.tr https://orcid.org/0000-0003-4042-7626 
of charged- or free-on-street parking, or illegal parking. In this study, changes in on-street parking users' behavior in Istanbul were analyzed as hours, days, months, seasons and years with taking advantage of the car parking data for about last 8 years. Effects of fee increases and short-term free parking practices were also examined. As a result of the study; It was found that 20 percent of the day parking entry was between 09.00 and 11.00 , the maximum transactions occurred on Wednesday the middle day of the week, both the minimum transactions and the longest average parking time took place on Sunday. In addition, the average parking duration of the vehicles in on-street parking was increased year after year, furthermore the occupancy (parking index) in European side was reached 86 percent between 14.00 and 15.00, and the average parking time was about 2 hours. In another important investigation, in that 0-15 minute free parking option applied on on-street parking was temporarily removed; there were a marked decrease in parking turnovers, and increase in a rate of collection, income per transaction and the average parking time. However, when the 0-15 minute-free parking option was reapplied, a significant increase in assessment and collection rate was observed and positive effects on payment behaviors of parking users were determined.

Keywords: Parking behavior, on-street parking, parking time and fee, 0-15 minute-free parking.

\section{GíRiş}

Kentiçi ulaştırma sisteminde ortaya çıkan park etme gereksiniminin, planlı ve sistematik bir şekilde yönetilmesi; bir taraftan trafik tıkanıklıklarında gözle görülür iyileşmeler sağlarken, diğer taraftan ulaşım planlamalarının etkili araçlarından birini oluşturmaktadır [1]. Otoparklar; ücretlendirme, kısıtlama ve sıkı kontroller ile trafik talep yönetiminin bir aracı olarak değerlendirilmektedir. Kendi tarihselliği içinde gelişen, değişen ve çeşitlenen otopark arz politikaları temelde geleneksel, piyasa odaklı ve talep yönetimi (otopark yönetimi yaklaşımı) olmak üzere üç farklı yaklaşımla yürütülmektedir [2-6]. Geleneksel yaklaşım; otopark talebini kontrol eden veya yöneten uygulamaları değil otopark talebini karşılamaya yönelik sunumu ölçen uygulamaları içermektedir [2-3]. Bu yaklaşım, otomobil odaklı olup, park yeri ihtiyacının araç sayısı arttıkça arttırılmasına ve her fonksiyonun birbirinden bağımsız olarak otopark temin etmesine dayanmaktadır. Gelişmekte olan ülke kentlerinde gözlemlenen bu yaklaşımda otopark sorunu arz sorunu olarak görülmekte olup "talebi tahmin et ve gerekli arzı üret” şeklinde bir yaklaşımla yürütülmektedir. Piyasa-odaklı yaklaşımda ne kadar park alanı sunulacağı arz-talep etkileşimi içinde belirlenmektedir. Bu yaklaşım, araçların gece parklarında özellikle yol-kenarı park talebinin arzı geçtiği alanlarda özel amaçlı park alanları olarak ortaya çıkmaktadır. Otopark talep yönetimi ise Kuzey Amerika ve Avrupa'da uygulanan bir yaklaşım olup, diğer ulaşım türleri ile entegre bir otopark politikası oluşturulması esasına dayanmaktadır. Toplu taşımanın etkin kullanımına yönelik olarak, merkezi alanlara özel araçlı yolculukları azaltacak park et devam et $(\mathrm{P}+\mathrm{R})$ otoparklarının yapılmasını teşvik eden ve otopark talebini ücret, süre ve kısıtlamalara dayalı bir şekilde yöneten bir yaklaşımdır [2-5]. Otopark talebini karşılamak amacıyla sadece otopark kapasitesini arttırmak araç sahipliğini ve kullanımını teşvik ederken, diğer ulaşım türlerini/seçeneklerini zayıflatma potansiyeline sahiptir [7]. Bu yaklaşımı diğer yaklaşımlardan farklı kılan temel husus, sadece doğrudan maliyetlere değil, dolaylı maliyetlere de odaklanarak otopark talebinin kontrol edilmesi ve yönetilmesidir [8-10]. 
Otopark yönetimi temelde otopark arzının verimli kullanılmasını sağlayacak politika ve programları içerir [5]. İstanbul için ikili otopark politikasına ihtiyaç vardır. Bir taraftan otopark sunumu yapılırken, diğer taraftan da mevcut otoparkların yönetimi ve piyasa koşullarında değerlendirilmesi gerekmektedir. Bunun için de sokakların ciddi anlamda kontrol edilmesi gerekmektedir.

$\mathrm{Bu}$ çalışmada İstanbul'daki yol kenarı otoparklardaki uygulamaların kullanıcı davranışlarında oluşturduğu değişimler, yaklaşı 8,5 yıllık otopark verilerinden yararlanarak; saat, gün, ay, mevsim ve yıllara göre analiz edilmiştir. Bu amaçla mevcut çalışma, beş bölümde tasarlanmıştır. Birinci bölümün devamında konu ile ilgili literatür özeti verilmiştir. İkinci bölümde; nüfus, demografi ve araç sahipliği, otopark algısı, talebi ve ücretlendirme, otopark arzı ve yol kenarı otopark işletmeciliği gibi İstanbul'a ilişkin bazı ulaşım ve otopark göstergelerine değinilmiştir. Üçüncü bölümde; analizde incelenen ana konular, parametreler ve bu parametrelerle ilgili açıklamalar ile giriş ve günlük otopark ücretleri, kapasite, çalışan personel sayısı gibi analize konu olan otoparkların temel özelliklerine yer verilmiştir. Dördüncü bölümde hem İBB Ulaşım Ana Planı (2011) hem de İBB Otopark Ana Planı (2016)'nda yer almayan kullanıcı davranışlarındaki değişimler veri tabanında kayıtlı verilerden yararlanılarak hem saat, gün, ay, mevsim ve yıllara göre hem de ücret artışının ve kısa süreli ücretsiz park uygulamalarının etkileri ile doluluk oranlarındaki değişim incelenmiş, grafikleri oluşturulmuş ve analiz edilmiştir. Ayrıca mevsim bazlı ortalama park süresi zaman serisiyle incelenmiştir. Bir diğer konuda yol kenarı ve yol dışı otoparklarda uygulanmakta olan ücretlendirme yaklaşımı ve ücretlendirmenin temel bileşenleri verilmiştir. Aynı kısımda ulaşım ana planında verilmiş olan otopark ücretlendirme modeli Stata 14 yazılım programı kullanılarak regresyon analiziyle incelenmiş ve tutarsızlığı tespit edilmiştir. Son bölümde ise çalışmadan çıkarılacak sonuçlara ve geliştirilebilecek yol kenarı park politikalarına yönelik önerilere değinilmiştir.

\subsection{Literatür Özeti}

Bu kısımda; düzenlenmiş otoparklar ve yönetilmesi, yol kenarı otopark ücretlendirmelerine örnekler, ücret ve süre politikalarının etkileri, doluluk oranı, performansa dayalı (hassas) ücretlendirme, otopark ücretlerindeki artışın etkisi, İstanbul'daki yol kenarı otopark işletmeciliği ve çok işlevli el terminallerinin kullanılması, ücretsiz otopark sunumu ile trafiğin akışını bozacak parklanmalar başlıklarında kısa bir literatür özeti verilmiştir.

Düzenlenmiş otoparklar ve yönetilmesi: Düzenlenmiş otoparklar; ekonomik, sosyal, ekolojik, mobilite ve şehir yönetimi (imar ve tesis) açısından ciddi faydalar sağlayarak otopark sorunlarının giderilmesinde en iyi çözüm araçlarından biridir [11]. Fatih ilçesi Oğuzhan Caddesi araştırma alanında yapılan ölçüm ve analizler sonucu elde edilen veriler doğrultusunda, uygulanan ideal park etme stratejisiyle araç geçiş yoğunluğunda $\% 4,94$ ve trafik akış hızında \%7,92 artış görülmüștür. Uygulanan ideal park etme stratejisi sonrası trafik yoğunluğunda azalmanın etkisiyle referans alınan egzoz emisyon sonuçlarına göre egzoz emisyon kirleticilerinde \%6,20 oranında da azalma gerçekleşmiştir [12].

Yol kenarı otopark ücretlendirmelerine örnekler: Chicago'da yol kenarı iki saatlik park ücreti 13 \$ iken, San Francisco'da ve New York City'de ise 12 \$'dır [13]. Amsterdam'da ise 2015 yılı verileri baz alındığında otopark ücretleri saatlik $5 €$ ve günlük $40 €$ düzeylerindedir [14]. Ayrica ortalama saatlik ücretler, Paris'de $4 €$, Londra'da $8 €$ ve Barselona 3,7 €'dur. 
Aynı şehirlerdeki günlük ücretler sırasıyla $36 €, 48 €$ ve $25 €$ 'dur. Avrupa'da 32 şehirdeki ortalama saatlik ücret ise $3 €$ 'dur [15].

Yol kenarı otoparklarda ücret ve süre politikasının etkileri: Otopark talebini yönetmek üzere atılan ilk adımlar "ücret" ve "süre" politikaları olmuştur [9]. Ücretlendirme stratejileri, genellikle tekil hedeflerden çok, bir hedef kombinasyonuna ulaşmak amaciyla kullanılmaktadır. Mevcut durumda pek çok otopark yeri, yetersiz fiyatlandırıldığından, tüketicilerin ödedikleri ücretler, otopark kullanımlarının gerçek maliyetini yansıtmamaktadır [16]. Hollanda'da park ekonomisi üzerine yapılan bir çalışmada yol kenarına park etme fırsatı ile park zamanı arasındaki ilişki incelenmiş ve 90 dakikalık bir parklanmada park etme firsatının \%25'in altına düşeceği belirtilmiştir [17]. Yapılan bir başka çalışmada otopark ücretlendirme ve süre sınırlandırmasıyla yol kenarında \%26 düzeyinde bir talep azalımı olabileceği belirtilmiştir [18]. İstanbul'da otopark ücretlerinin belirlenmesinde belirli bir sistematik yaklaşım yoktur. Her işletme kendi ücret tarifesini kendi tayin etmektedir. Bazı yol kenarı otoparklar; yol dışı, açık ve kapalı otoparklardan daha ucuz olabilmektedir.

Hâlbuki yol kenarı otoparkları, yol dışı otoparklardan daha pahalı tutmakla sürücülerin yol dışı otoparkları tercih etmesi teşvik edilebilir [19-20]. Böylece park yeri arama süresinin dolayısıyla sıkışıklığın, trafik odaklı emisyonların ve intikal sürelerinin azaltılması sağlanmış olur [20].

Otoparkların tam fiyatlandırması, katlı otoparklarla yol kenarı ve yol dışı otoparkları eşit maliyetli yapan seyir düzeyi arasındaki etkileşimdir. Çok az sayıda çalışma, katlı otopark kullanıcılarının davranışlarını ve yol kenarı ile yol dışı otopark düzenleme araçları arasındaki etkileşimleri (yani ücretler, zaman sınırlamaları, park izinleri, park alan tipleri ve bunların mekansal dağılımı veya denetim düzeyi gibi) analiz etmiştir [21].

Otopark talebiyle ilgili yapılan ampirik çalışmalar büyük ölçüde, yol kenarı otopark düzenlemelerinin taşıtın seyahat seçenekleri üzerindeki etkilerine tercih anketleri kullanarak odaklanmışlardır [22]. Yol kenarı park talebi; gelirle azalmakta [23-24], kalma süresiyle [2526], seyahat amacına bağlı olarak [27-28] ve alternatif ulaştırma modlarının düzeyiyle artmaktadır [29-30]. Ek olarak, talep segmentlerinin heterojen ve nonliner olmas1 beklenmektedir [27,31]. Yapılan bir başka çalışmada bir meta analiz regresyonuna dayanarak, ABD için biraz daha düşük $(-0,30)$ ve ABD dışı çalışmalar için çok daha yüksek $(-0,86)$ olan park ücretine göre -0,39'luk ortalama talep esnekliği tespit edilmiştir [22]. Farklı çalışmalarda yol kenarı ve katlı otopark talebinin, otopark ücreti ile negatif ilişkili olduğu tespit edilmiştir [26,32]. Ancak katlı otopark talep esnekliği; 60 ve 20 dakikalık park süreleri için sırasıyla $-2,2$ ile $-1,5$ aralığında hesaplanmıştır [26].

Ampirik literatür, yaygın şekilde yol kenarı otoparklara odaklanma eğilimindedir ve genellikle katlı otoparkları basit bir dış seçenek olarak kabul etmektedir. Daha önce yapılan çalışmalarda yol kenarı park düzenleme araçlarının, kat otopark talebi ve özel işletmelerin fiyat belirleme davranışlarına olan etkileri dikkate alınmamıştır. Yürütülen çalışmada otopark talebi üzerine (hem zaman hem de aboneler için), kat otoparkı ücretinin ve yol kenarı otopark düzenleme özelliklerinin (ücret ve özel alanların türü gibi) etkisi analiz edilmiştir [33].

Otopark doluluk oranı: Kamuya ait yol kenarı parkların kullanım oranları için temel opsiyonlar; zaman sınırı, imtiyazlı ya da rezerve erişimler (izinler) ve ücretlendirme olarak sayılabilir [34]. Otopark ücretlendirme opsiyonu; arz ile talebi dengelemek, yol kenarı ve yol 
dışı otoparklar arasındaki talebi, talep dağılımını, park etme süresinin uzunluğunu ve kullanıcı değişikliğini/alışkanlıklarını ve gelir seviyesini etkilemek için kullanılabilir. Ayrıca doluluk oranları, ücretleri ve sınırlı otopark kapasitesi gibi hususlar sürücü davranışlarında; alternatif park yeri bulma, seyahate başka bir zamanda başlama, farklı bir ulaşım modu seçme, varış yerini değiştirme ve seyahatin tamamından kaçınma olarak beş farklı etki oluşturabilmektedir [35]. Konunun uzmanları tarafından, otopark alanlarının \%15'inin boş olmasının sürücülerin park yeri bulmak için harcadıkları zamanı en aza indirmeleri açısından en uygun oran olduğu belirtilmektedir. Bunun yönetilmesi için ücretlendirme yeniden gözden geçirilmelidir [35-38]. Literatürde \%85-90 doluluk oranı gözetilerek yapılan ücretlendirme, performansa dayalı ya da hassas ücretlendirme olarak tanımlanmaktadır [36-37]. Son zamanlarda bazı şehirlerde doluluk oranına bağlı olarak dinamik ücretlendirme yöntemi benimsenmektedir. Örneğin San Francisco'da saatlik ücret minimum 0,5 ve maksimum 8 \$ düzeylerindedir. Saatlik ücretlerin doluluk oranındaki değişime bağlı olarak uygulanabileceğine dikkat çekilmiştir. Doluluk oranı $\% 80$ ve üzeri olduğunda, saatlik ücret $0,25 \$$ artırılır, doluluk oran $1 \% 60$ ve üzerindeyse ancak yüzde 80 'in altındaysa, saatlik ücret değiştirilmez ve doluluk oranı \%60'ın altındaysa, saatlik ücret 0,25 \$ düşürülür [39].

Otopark ücretlerindeki artışın etkisi: Otopark ücretlerini arttırmak, yol ağında etkinlik artış1 sağlayarak park cirosunda meydana gelen artışın ötesinde bir refah kazancı sağlayabilecek potansiyele sahiptir. Şayet park fiyatlarını arttırmak politik olarak riskli ise ve özel otoparkların sağlanması maliyet bakımından mümkün olamıyorsa, ikinci en iyi politika seçeneği yol kenarı park yeri kapasitesini yol kenarı park yeri aramayı yok edene kadar arttırmaktadır [40]. Otoparkların stratejik yönetiminde ücretlendirme parametresi kullanılarak, parklanma \%10 ile \%30 arasında azaltılabilir [9]. Otopark ücretlerindeki $\% 10$ 'luk artışın; 2 saate kadar park eden sürücülerin park talebinde \%1; 2 ile 4 saat arasında park eden sürücülerde ise \%3'lük bir düşmeye, ayrıca Birleşik Devletlerde otopark ücretlerindeki \%10'luk artışın ise araç seyahatlerinde \%1 ile 3 arasında bir azalmaya neden olacağı belirtilmiştir [41]. San Francisco'da doluluk oranına bağlı uygulanan dinamik ücretlendirme örneğinden hareketle çeşitli araştırmacılar, park ücretlerinde \%10'luk artışın, talebi \%3 ile 10 arasında azaltabileceğini tespit etmişlerdir [42].

Şehirlerdeki otopark problemi, arama trafiği ve etkileri: Şehirlerdeki otopark sorunu; trafik tıkanıklığı, trafik kazaları ve çevre kirliliği gibi sorunlarla doğrudan ilişkilidir [44]. Araçların ortalamada \%30'u park yeri aramak için dolaşmakta ve bu iş için ortalama 8,1 dakika harcamaktadırlar. Park yeri aramakla geçen bu zaman ciddi bir refah kaybına neden olmaktadır [36, 44]. Otopark arama trafiğinin ortalama 3,5 ile 13,9 dakika arasında değişebildiği belirtilmiştir [45]. Trafik yoğunluğunun \%14'ünü otopark yeri arayan araçların oluşturduğu tahmin edilmektedir. Ayrıca bu durumun tıkanıklığa bağlı zaman kaybında ise \%50'lik bir artış meydana getirdiği belirtilmektedir [46]. İstanbul'da 537 sürücüyle yapılan bir ankette sürücülere otopark yeri ararken harcadıkları zaman sorulmuştur. Katılımcıların $\% 51,2$ 'si günde 0-5 dakika, \%28,7'si günde 6-10 dakika, \%11,9'u ise günde 11-15 dakika park yeri aradıklarını ifade etmiştir [47]. Birleşik Devletlerde yapılan araştırmalarda ticari merkezlerdeki trafik sıkışıklıklarının \%8-74 arasında yol kenarında park alanı bulmaya çalışan araçlardan kaynaklandığı belirtilmektedir [48]. INRIX tarafından 6.000 Amerikalı ve 12.000 'de Büyük Britanya ve Almanyalı sürücü üzerinde yapılan araştırmalarda; Amerikalıların yılda park yeri aramadaki zaman kaybı, yakıt tüketimi ve emisyon yükünün oluşturmuş olduğu maliyet 73 milyar \$ olarak tespit edilmiştir. Bu değer ülke genelinde kişi başına yılda ortalama 345 \$'a, Chicago'da ikamet edenler için ise 1.174 \$'a tekabül 
etmektedir. Yine aynı raporda park probleminin bölgesel ekonomiye etkisi olmaktadır. Araştırmaya katılan Amerikalı sürücülerin $\% 63$ 'ü varılan yerdeki park yeri bulma güçlüklerinden dolayı ve yine $\% 39$ 'u benzer gerekçelerden dolayı alışveriş merkezlerine gitmekten kaçındıklarını belirtmişlerdir [13].

İstanbul'da yol kenarı otopark işletmeciliği: 2008 y1lından bugüne kadar yol kenarı otoparklardaki ödeme ve kontrol, personele dayalı bir sistemle el terminalleri üzerinden yürütülmektedir. Çok işlevli el terminalleri, park etme beyanının hem elektronik hem de görevli esasına göre yapılabileceği bir yazılımla kullanılmaktadır. Taşıt, park yerine girdikten sonra görevli tarafından ilgili peron numarasına göre sisteme manuel (elle) aracın plakası yazılır ve taşıt sürücüsünün kalmayı düşündüğü süre öğrenilerek ilgili seçeneklerle sisteme giriş yapılır [49-52].

Ücretsiz ve kontrolsüz otopark sunumu: Yol kenarı park yerleri gereğinden ucuz sağlanıyor olsa da olmasa da yüksek talep yoğunluklarında yol kenarı park yeri sağlamak optimal değildir. Bunun yerine yolu trafik akışı için kullanmak daha optimal olacaktır [40]. Parklanma konusunda yazılmış ve belki de toplum nezdinde en büyük etkiyi oluşturmuş eserlerden biri Shoup'un (2005) The High Cost of Free Parking isimli eseridir. Yazar bu eserde özetle kentlerde park alanları için doğru miktarda yer ayırmamanın ve park yerlerini doğru fiyatlandırmamanın toplum refahını nasıl olumsuz etkilediğini ve bu bağlamda "ücretsiz otopark" diye bir şeyin olmadığını belirtmektedir [36]. Park yerleri iktisadi anlamda bir ara üründür ve bu ürün gereği gibi "fiyatlandırılmıyorsa" muhakkak ki bir "kapasite" problemi ortaya çıacaktır. Bu kapasite problemi, kent merkezlerinde park yerlerine ayrılabilecek arazi miktarı kısıtlı olduğu için ancak uzun vadede çözülebilecek bir problemdir. Kaldı ki bütün kentte her bir araç için iki park yeri temin edilse dahi park yeri sıkıntısı yaşandığı durumlar mutlaka olacaktır [53].

İkinci sıra ve yolun sol kısmındaki usulsüz parklar trafik akışını olumsuz etkilemektedir. Literatürde belirtildiği üzere ikinci sıra parkların önlenmesiyle, gecikmelerde \%33'e ve durma zamanlarında \%47'ye kadar azalma sağlanabilirken, ortalama trafik akış hızlarında $\% 44$ 'e kadar bir artışta elde edilebilmektedir [54]. Otopark yetersizliğine bağlı olarak ortaya çıan ve varlığı ile otopark yetersizliğini arttıran sorunlardan biri de ücretsiz otopark yerlerinin işgal veya gasp edilmesidir. Yani kişilerin kendi mesken veya iş yerlerinin önündeki yol kenarı parkları sahiplenerek başka kullanıcılara izin vermemesidir. Bu durum İstanbul genelinde son derece yaygın olarak gözlemlenmektedir. Park yeri gaspı hem kamusal kaynakların adaletsiz kullanımına neden olmakta hem de otopark kullanıcıları arasında tartışmalara/sorunlara sebebiyet vererek, kamusal düzenin bozulmasına neden olabilmektedir. Araç geçiş yollarına ve yaya güzergahları üzerine hatalı park edilen araçlar hem ilgili bölgedeki araç trafiğini olumsuz etkilemekte hem de yaya konforunu ve güvenliğini tehdit etmektedir. Hatalı park edilen araçlar acil durumlarda ulaşımı sekteye uğrattı̆̆ından, can ve mal kaybı açısından risk oluşturmakta ayrıca görüntü kirliliğine neden olarak kentsel estetiği de bozmaktadır [19].

\section{2. İSTANBUL'A İLISSKIIN BAZI ULAŞIM VE OTOPARK GÖSTERGELERI}

İstanbul birçok dünya metropolü ile benzer bir otopark gelişimi yaşamıştır. Tarihsel olarak otomobil sahipliliğinin az ve sokakların park etmeye elverişli olduğu dönemlerde otopark önemli bir sorun olmamıştır. Ancak otomobil sahipliliğinin arttığı, sokak ve caddelerin park 
etmek için yetersiz kaldığı ve son yıllarda yol dışında bölge otoparkı yatırımlarının yapılmasıyla bu sorunun giderileceği şeklinde geleneksel bir yaklaşımla yönetilmektedir. Mevcut durumda yürütülen bu yaklaşımla da otopark talebinin park yeri temin etme ile karşılanamayacağı açıktır [5]. İldeki nüfus, kayıtlı motorlu araç sayısı ile İSPARK AŞ'nin işlettiği otopark kapasite ve işlem sayıları Tablo 1'de gösterilmiştir. Tablodan; ildeki araç sayısının hızla arttığı ve nüfus artış hızının yavaşladığı görülmektedir.

Tablo 1 - İstanbul nüfusu, araç saylsı ve IBB' 'nin otopark kapasite ve işlem sayısı [55-58]

\begin{tabular}{|c|c|c|c|c|c|c|c|c|}
\hline & \multicolumn{2}{|c|}{ Otopark İşlem Sayısı } & \multicolumn{2}{c|}{$\begin{array}{c}\text { IBB Otopark } \\
\text { Kapasitesi }\end{array}$} & \multicolumn{2}{c|}{ Araç } & \multicolumn{2}{c|}{ İstanbul Nüfusu } \\
\hline Y11 & Sayı & $\begin{array}{c}\text { Art1ş } \\
\text { oranı, } \%\end{array}$ & Sayı & $\begin{array}{c}\text { Artış } \\
\text { oranı, \% }\end{array}$ & Sayı & $\begin{array}{c}\text { Artış } \\
\text { oranı, \% }\end{array}$ & Sayı & $\begin{array}{c}\text { Artış oranı, } \\
\%\end{array}$ \\
\hline 2013 & 26.016 .588 & - & 61.221 & 5,0 & 3.230 .908 & 5,0 & 14.160 .467 & 2,2 \\
\hline 2014 & 31.926 .280 & 23 & 77.984 & 27,4 & 3.383 .812 & 4,7 & 14.377 .018 & 1,5 \\
\hline 2015 & 35.368 .829 & 11 & 80.913 & 3,8 & 3.651 .166 & 7,9 & 14.657 .434 & 2,0 \\
\hline $2016^{*}$ & 37.249 .869 & 5 & 84.334 & 4,2 & 3.875 .145 & 6,1 & 14.804 .116 & 1,0 \\
\hline $2017^{* *}$ & 18.957 .678 & - & 83.583 & - & - & - & - & - \\
\hline
\end{tabular}

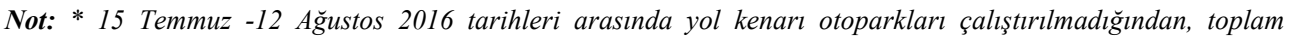
1.080 .000 işlem kaybı olmuştur. ** 2017 yılı verileri ilk 6 ayı kapsamaktadır.

\subsection{Nüfus, Demografi ve Araç Sahipliği}

İstanbul'un demografik yapısı oldukça dinamik ve değişkendir. Nüfus ve nüfus yoğunluğu hem iç hem de dış dinamiklerle sürekli artmakta, ortalama hanehalkı büyüklüğü ise düşmektedir. Merkezi ilçelerde nüfus azalmakta, buna karşın dış çeperlerde yer alan toplu konut ve site türü yerleşim alanlarında ise nüfus artış eğilimi devam etmektedir [59].

Araç ya da otomobil sahipliği, bütün ülkeler için kullanılan genel bir birimdir. İlde yaşayan her 1000 kişinin kaçının araç ve kaçının otomobil sahibi olduğunun anlaşılmasını sağlar ${ }^{1}$. İstanbul'da 2016 yılı sonu itibarı ile araç sahipliği 260 Araç/1.000 Kişi ve otomobil sahipliği ise 178 Otomobil/1.000 Kişi olarak hesaplanmıştır ${ }^{2}$. Bu değer, İstanbul için zamanla artma eğilimindedir. Son 10 yılın değerleri dikkate alındığında İstanbul'da her gün ortalama 355 yeni otomobilin tescili yapılmaktadır. Bu değer, yaklaşık büyük bir katlı otoparkın araç sığasına eşdeğerdir. Diğer bir ifade ile İstanbul'da trafiğe katılan araçlar için her gün büyük bir katlı otopark yapılması sadece trafiğe yeni katılan araçlara cevap verebilecektir. 2000 yılında otomobil sayısı 1 milyon ve nüfus 10 milyon iken, 2016 yılı sonu itibariyle otomobil sayısı yaklaşık 2,644 milyon, nüfus yaklaşık 14,8 milyon seviyesine ulaşmıştır (Şekil 1). Son 16 yıl içinde otomobil sayısının artış yüzdesi, nüfus artış yüzdesinden yaklaşık 3,5 kat daha hızlı olmuştur.

\footnotetext{
${ }^{1}$ Literatürde araç sahipliği; ya hane başına, kişi başına ya da yetişkin başına (18 yaşından büyük olanlar) araç sayısı olarak karşımıza çıkabilmektedir [14].

2 İstanbul 2,669 milyonu otomobil olmak üzere 3,875 milyonluk araç parkına sahiptir [56].
} 


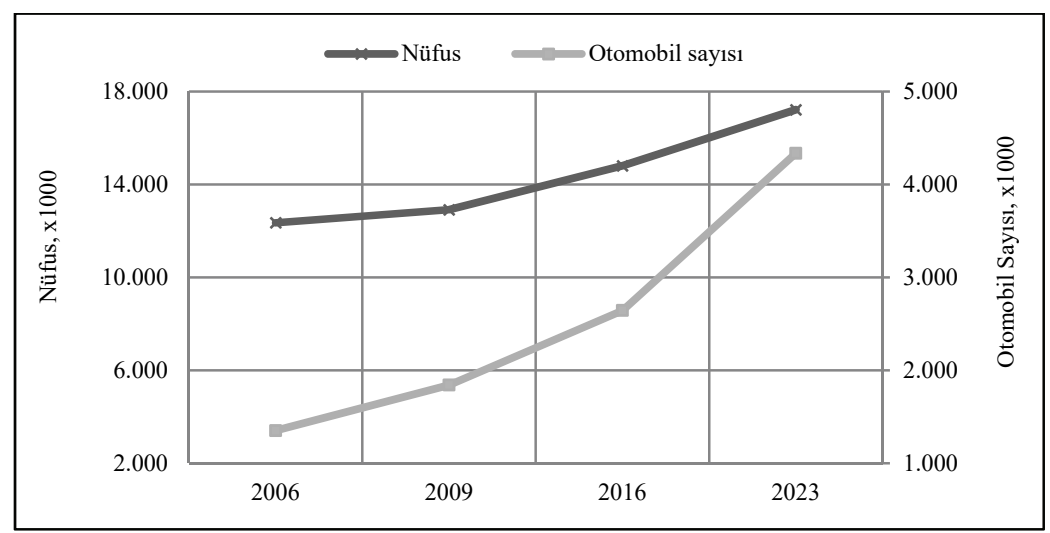

Şekil 1 - İstanbul'un yıllara göre nüfus dağılımı, otomobil sayısı değişimi ${ }^{1}$ [56-59]

\subsection{Otopark Algısı, Talebi ve Ücretlendirme}

Otopark alanı toplum tarafindan ücretsiz sunulan ve/ya sunulması gereken ortak bir alan olarak algılanır. $\mathrm{Bu}$ algı otomobil sahiplerinin konutları civarında uzun parklanmalarının ücretsiz olması gibi bir algıyı da beraberinde getirmektedir. Başka amaçlarla kullanılabilecek alanlar ücretsiz otopark olarak kullanıldığında bir firsat maliyeti doğmaktadır. 2006 ve 2012 Ulaşım Ana Planı hane halkı anketleri incelendiğinde 2006 yılında sokağa park etme oranı $\% 62,1$ iken 2012'de bu oran \%70,07 seviyelerine gelmiştir. Bu bağlamda sokakta park etmenin giderek mekâna yayıldığı, konut alanlarında yapı ya da parsel bünyesinde yeterince otopark alanının olmadığı ve abonelik yoluyla ücretli otoparka park etme alışkanlığının da zayıf olduğu belirtilmektedir [35]. Ayrıca akşam ve gece vakitlerinde konut yakınlarında otopark alanı bulunamaması, gündüz vakitlerinde ise ana arterlerde ve ticari merkezlere yakın otoparklarda taşmaların olması otoparkları daha önemli hale getirmiştir.

Gayrimenkul ve Gayrimenkul Yatırım Ortaklığı Derneği’nin (GYODER) 2015 yılında hazırladığ1 "Gayrimenkul Sektörü ve İstanbul Konut Piyasası Saha Araştırma Raporu" sonuçlarına göre yapılarda otoparkın varlığı \%13,6 oranında bir değer ile ikinci sırada konutun fiyatına olumlu etkide bulunmaktadır. Aynı araştırmanın konut alırken dikkat edilen hususlar konusundaki cevaplar incelendiğinde ise; yapıda otopark olup olmamasını birinci öncelikli tercih görenlerin oranı \%6,4 iken, verdiği tüm cevaplar dikkate alındığında ise yaklaşık \%10'luk bir oranda konutta öncelikle otopark arandığg göstermektedir [35].

Şehrin merkezindeki mevcut otopark talebi, buradaki kentsel işlevlerin yeri, tipi, yoğunluğu ile aynı zamanda park yerlerinin varlığı, ücreti ve toplu taşıma sisteminin kullanım düzeyi ile ilgilidir. Günümüzde İstanbul'un merkezindeki otopark talebini; otomobil sahibi olan merkezdeki işyeri çalışanları, iş takibi nedeniyle merkeze gelenler ve alışveriş-gezi eğlence amacıyla gelenler oluşturmaktadır.

Geneli itibari ile özel otomobiller günde 1-3 saat hareketli iken, 20 saatin üzerinde bir park yerini işgal etmektedir. Her bir park yeri alan bazlı olarak 15 ile $30 \mathrm{~m}^{2}$ arasında bir alanı

\footnotetext{
${ }^{1}$ İstanbul için 2023 yılı otomobil sahipliği hesaplanırken otomobil sayısı yıllık artış oranı kullanılmıştır [59].
} 
kaplamakta olup gün içerisinde bir otomobil ortalama olarak en az iki farklı mekânda (örneğin ev ve işyeri) park yerine ihtiyaç duymaktadır [35].

Park etme davranışları ve talebi; bölgeleme, mekânsal değiş̧enlikler ve ikamet edilen bölge, ev sahipliği ve kiracı statüsü, bina tipi, gece - gündüz, haftaiçi ve sonu, mevsim ve otomobil özelliklerinin etkileri gibi alt başlıklarda incelenebilir. İstanbul'da hem otomobil sahipliği, hem de farklı parklanma türlerindeki arz, kent içinde mekânsal olarak değiş̧enlik göstermektedir. İstanbul'un farklı kentsel gelişim eğilimleri, mekânsal olarak otopark ihtiyacı ve arzını da farklılaştırmaktadır. Üç temel mekânsal değişken öne çıkmaktadır: $\mathrm{Yaka}^{1}$, kent merkezi ve ücretli otopark arzı. Her bir bölgenin özelliği gece oluşacak talebin değişimi, sokak parklanmasının ortaya çıkardığı park alan baskısı ve bu parklanmaların gün içerisindeki dağılımları ile değişmektedir [35]. Ayrıca toplam yol kenarı parklanma kapasitesinin \%59'u Avrupa Yakası'nda ve geri kalan \%41'lik kısmı ise Anadolu Yakası'ndadır. Sabah 08.00'den 19.00 kadar son 7,5 yıllık veriler incelendiğinde; araç başına yol kenarında ortalama park etme süresi Avrupa yakasında yaklaşı 2 saat ve Anadolu yakasında ise 1,5 saatin üzerindedir [55].

Gün içerisinde zaman ve mekânda farklılıklar arz eden parklanma davranışları, haftalık farklılıklar da göstermektedir. Hafta içi genelinde iş ve okul yolculukları dışında farklı faaliyetlerin aktif olduğu zamanları içermektedir. Birçok faaliyet hafta sonuna geçiş ile hafta sonu tatiline girmekte, dolayısı ile özellikle iş ve okul faaliyetleri ile ilişkili olanlar hafta içi gözlemlendiği şekli ile gündüz parklanmalarının azalmasına katkıda bulunmaktadır. Buna karşın farklı mahallerde gündüz parklanmasının yoğunlaşmasına neden olmaktadır. Parklanma davranışları mevsimlik farklılıklar da göstermektedir. Yı1 içerisinde yaz-kış döngüsü, okulların tatil olması, yaz aylarında şehir dışına çıkılmasının sıklaşması gibi nedenlerle park talebinde azalma olmaktadır. Gündüz ve ara parklanmaların zaman ve mekânda sezonlara göre hafta sonlarında değişkenliğinin ortaya çıkardığı park alan arzının talep değişkenliğine uyumlu olarak esnek olmasını desteklemektedir [35].

Yol kenarı park ücretleri, otopark arayarak trafiği yavaşlatan araç sayısını azaltmak ve kaldırım alanlarının kullanımını iyileştirmek için düzenlenmektedir [35]. Bölgesine göre yol kenarı otoparklarda genellikle $0-1$ saat giriş ücreti olarak 7 ile 8 TL ve kısmen de 0-2 saat girişte aynı ücretler uygulanabilmektedir. Sonraki ilave saatlerde genellikle 1 bazen de 2 TL gibi ücretler giriş ücretine ilave edilmektedir. Günlük ücretler yaygın olarak minimum 12 TL, maksimum 20 TL'ye kadar çıkabilmektedir. İstanbul'da ISPARK tarafından işletilen yol kenarı otoparklardaki ücretler, yüksek fiyattan daha düşük fiyata doğru bir politikayla

\footnotetext{
${ }^{1}$ Anadolu Yakasında büyük parselleri olan konaklar yerine yüksek katlı apartmanlar yapılmış, Avrupa Yakasında ise daha küçük parseller üzerinde olan binalara ya kat eklenmiş ya da bina tamamı ile yıkılarak yeniden ve daha yüksek katlı olarak inşa edilmiştir. Anadolu Yakasında daha önce konakların parselleri içinde yapılan yüksek katlı apartmanların otopark ihtiyacı parsel içinde bırakılan açık alanlarda karşılanırken, Avrupa Yakasında açık alan bırakmadan mevcut binaların oldukları yerde yükselmesi ile ortaya çıkan konut alanlarında otopark ihtiyacı ancak sokaklarda çözülmüştür. Her iki durum zaman içerisinde artan araç sayısı ile değişik ölçülerde yetersiz kalmaya başlamıştır. Anadolu Yakasında yavaş yavaş parsel içindeki alanlardan sokaklara doğru yayılma gözlenirken Avrupa Yakası'nda da sokakların park açısından kullanımının yoğunluğu giderek artmıştır. İstanbul'un en yoğun yapılaşmış olan alanları olarak öne çıkan Fatih, Beyoğlu, Beşiktaş, Üsküdar ve Kadıköy ilçelerinin yerleşme tarihi çok daha eski dönemlere dayanmaktadır. İstanbul genelinde yola park etme ortalaması 0,59 seviyesindedir. En yüksek yola park etme oranı olan ilçe 0,75 ile Fatih ilçesidir. Ayrıca 0,70 üstünde yola park etme oranı gerçekleşen ilçeler ise Beyoğlu, Gaziosmanpaşa, Kağıthane, Esenler, Güngören, Zeytinburnu ve Arnavutköy'dür. Ücretli otopark sunumunun diğer ilçelere göre fazla olduğu Şişli ve Fatih ilçelerinde alternatif parklanma için ilçenin mekânsal ve yapısal özellikleri imkân tanımamaktadır. Hem yol kenarı hem de parsel-bina otopark alanları kısıtlıdır. Bu da ücretli otoparkların seçilmesine etki eden bir sebep olarak ortaya çıkmaktadır [35].
} 
yürütülmektedir. $\mathrm{Bu}$ durum araç sürücülerinin belli düzeyde ücretsiz otopark arayışına itilmesine neden olmakta; dolayısıyla arama trafiği ve otopark sorununu arttırıcı etki oluşturmaktadır. İstanbul için park yeri arama süresi yaklaşı 5,6 dakika olarak hesaplanmıştır ${ }^{1}$.

\subsection{Otopark Arzı ve Yol Kenarı Otopark İşletmeciliği}

Otopark arzı temelde yol dışı ve yol kenarı olarak sınıflandırılabilir. Yol kenarı otoparklarda parklanma yapılıp yapılmadığı, parklanma şekli, parklanma yönü, kapasite, varsa ücret ve işletmeci bilgisiyle; yol dışı otoparklar ise, otoparkın yapım şekli, kat adedi, açık, kapalı ve toplam park kapasitesi, otoparkın kullanım amacı ve hangi fonksiyona ait olduğu, ücret ve işletmeci durumu gibi bilgilerle tanımlanmıştır. İOAP (2016)'a göre; İstanbul genelinde otopark arzı 1.984.733 iken, talebi ise 2.661.031'dir. Bu rakamlardan 710.113 araçlık bir otopark ihtiyacı bulunduğu tespit edilmiştir. Maltepe, Ümraniye, Bahçelievler, Bağcılar ve Üsküdar otopark ihtiyacının en çok olduğu ilçelerdir [35].

Otoparkların yapılış şekillerine göre dağılımı incelendiğinde; il genelinde 2.442 adet 168.119 araç kapasiteyle açık otopark, 406 adet 52.727 araçlık kapalı otopark bulunmaktadır. Geneli itibariyle kapasitenin \%76'sı açık alan düzenlemesi ile elde edilmiştir [35]. Tablo 2'de verilmiş olan yol dışı otoparklara konut dışı fonksiyon otoparkları ilave edilmemiştir. Ayrıca bu tabloda yer alan otoparkların işletmecisine göre dağılımı incelendiğinde; 2.491 adet otoparkın 146.528 araç kapasiteyle birlikte özel işletmeler; 357 adet otopark, 74.318 araç kapasitesiyle yani \%33,6'sı İSPARK tarafından işletilmektedir.

Konut dışı fonksiyon otoparklarının toplam kapasitesi 451.017 olup, bu kapasitenin \%31,6'sını alışveriş merkezleri ve \%15,8'ini ise iş merkezlerine ait otoparklar oluşturmaktadır. Özellikle büyük alan kullanıma sahip alışveriş merkezleri, fuar, havaalanı, marina, üniversite kampüsleri, rekreasyon alanları, mesire yerleri ve turizm tesis alanları bünyesindeki otoparkların kapasitesi de oldukça yüksektir [35].

İstanbul'da yol kenarı parklanmayı olumsuz etkileyen bina giriş-çıkışları, yol kesişimleri, kavşak başlangıç ve bitişleri, otobüs durakları, trafik sşıkları, okul ve yaya geçitleri, resmi kurum bina önleri, çöp konteynırları, trafo, çeşme, yangın musluğu, ağaç gibi kapasite kısıtlayıcı özellikler dikkate alınarak yol kenarı otopark kapasitesi tespit edilmiştir. Bu kabule göre yol kenarında toplamda $\mathbf{1 . 3 4 8 . 2 6 8}$ araçlık bir otopark kapasitesi bulunmaktadır. $\mathrm{Bu}$ kapasitenin \%59'u olan 803.688 araçlık kapasite Avrupa Yakası'nda ve geri kalan \%41'lik kısım olan 544.580 araçlık kapasite ise Anadolu Yakası'ndadır [35]. Şehirde toplam 24.859 km yol ağının 8.475 km'si üzerinde parklanma yapılmaktadır. Parklanma yapılan yol ağının $5.294 \mathrm{~km}$ 'si üzerinde tek taraflı, $3.181 \mathrm{~km}$ 'si üzerinde ise çift taraflı parklanma görülmektedir. Yol kenarı otopark kapasitesinin \%55'i (739.801 araç) çift taraflı, \%45'i (608.467 araç) ise tek taraflı park etmektedir. Geneli itibariyle yol kenarı otoparklar fiziksel tasarımı açısından yola paralel şekilde gelişmiştir. Parklanma yapılan yol ağının 8.126 km'si üzerinde kapasitesinin \%93'ü yani 1.249 .004 araçlık paralel park, 215 km'si üzerinde kapasitesinin \%4'ü yani 54.570 araçlık açılı park ve 134 km'si üzerinde kapasitesinin \%3'ü yani 44.694 araçlık dik açılı park şeklindedir [35].

\footnotetext{
${ }^{1}$ İstanbul'da 537 sürücüyle yapılan bir ankette sürücülere otopark yeri ararken harcadıkları zaman sorulmuştur. Katılımcıların \%51,2'si günde 0-5 dakika, $\% 28,7$ 'si günde 6-10 dakika, $\% 11,9$ 'u ise günde $11-15$ dakika park yeri aradıklarını ifade etmiştir [47].
} 
Yol kenarındaki otopark işletmeciliği İstanbul Büyükşehir Belediyesinin iktisadi teşekkülü olan ISPARK AŞ tarafından yapılmaktadır. Ancak Maltepe, Kadıköy ve Üsküdar ilçe belediyeleri de yol kenarı otopark işletmeciliği yapmaktadır ${ }^{1}$ (Tablo 2). Ayrıca şehrin bazı bölgelerinde çeşitli işyerleri tarafından yol kenarında vale hizmeti verilmek suretiyle işletmecilikte yapılmaktadır [35].

Tablo 2 - ISPARK AŞ’nin genel otopark envanteri ve diğer otoparklar [35, 55]

\begin{tabular}{|c|c|c|c|}
\hline İSPARK AŞ & Anadolu Yakası & Avrupa Yakası & Toplam \\
\hline Lokasyon sayıs1 & 186 & 456 & 642 \\
\hline Toplam otopark kapasitesi & 30624 & 61051 & 91675 \\
\hline Yol kenarı otopark kapasitesi & 4804 & 10081 & 14885 \\
\hline Yol dışı katlı otopark kapasitesi & 5543 & 16075 & 21628 \\
\hline Yol dışı açık otopark kapasitesi & 13703 & 27558 & 41261 \\
\hline Park et devam et otopark kapasitesi & 6574 & 7287 & 13861 \\
\hline Günlük ortalama işlem sayısı & 38896 & 63594 & 102490 \\
\hline \multicolumn{4}{|c|}{ Diğer İlçe Belediyeleri ve Özel İşletmeciler } \\
\hline & Diğer Belediyeler & \multicolumn{2}{|l|}{ Özel } \\
\hline Lokasyon sayısı & 3 İlçe Belediyesi ${ }^{2}$ & \multicolumn{2}{|l|}{2491} \\
\hline Toplam otopark kapasitesi & 1522 & \multicolumn{2}{|l|}{146.528} \\
\hline \multicolumn{4}{|c|}{ Otoparkların Yapılış Şekillerine Göre } \\
\hline & Adet & Kapasite & Toplam \\
\hline Açık otopark & 2.442 & 168.119 & 220.846 \\
\hline Kapalı otopark & 406 & 52.727 & 2.848 \\
\hline
\end{tabular}

İstanbul'da yol kenarı otopark işletmeciliği 2005 yılında İstanbul Otopark İşletmeleri Tic. AŞ - İSPARK AŞ’nin kurulmasıyla başlatılmıştır. Dip koçanlı fişle başlayan tahsilat 2008 yılında yerini aşamalı olarak el terminaliyle tahsilata bırakmıştır. SMS park 2009 yılında lokal bazda uygulanmış olmasına rağmen halihazırda kullanılmamaktadır. Çok işlevli el terminalleri, park etme beyanının hem elektronik hem de görevli esasına göre yapılabileceği bir yazılımla kullanılmaktadır. Taşıt, park yerine girdikten sonra görevli tarafından ilgili peron numarasına göre sisteme elle plakası yazılır ve taşıt sürücüsünün kalmayı düşündüğü süre öğrenilerek ilgili seçeneklerle sisteme girilir. Bu bilgilerin bir çıktısı sürücüye de verilir. Ödeme; nakit, kredi kartı, akıllı kart, önceden veya sonradan ödeme şekillerine cevap verebilecek altyapıya sahiptir [49-52].

Yol kenarındaki toplam 1.348.268 araçlık otopark kapasitesinin; 9 ilçe 49 lokasyonu Anadolu ve 17 ilçe ile 200 lokasyonu Avrupa yakasında olmak üzere toplamda 26 ilçede 249

\footnotetext{
${ }^{1}$ Ayrıca İSPARK tarafından Kadıköy'de 9 farklı yol kenarı lokasyonda 795 ve Üsküdar'da ise 7 farklı lokasyonda 561 araçlık ekstra kapasite işletilmektedir. Şirketin Maltepe'de yol kenarı otopark işletmeciliği bulunmamaktadır.

${ }^{2}$ Maltepe Belediyesi (Mapark): 200, Kadıköy Belediyesi (Kasdaş): 1245 ve Üsküdar Belediyesi: 80 araçlık kapasiteye sahiptir [35].
} 
lokasyonunda \%1,1'lik dilimi yani $\mathbf{1 4 . 8 8 5}$ araçlık kısmında İSPARK tarafından ücretli otopark işletmeciliği yapılmaktadır (Tablo 2) [35].

\section{MATERYAL VE METOT}

$\mathrm{Bu}$ çalışmada incelenen otoparklar ve parametreler açıklamalarıyla/gerekçeleriyle birlikte Tablo 3'de ve incelenen bir kısım otoparkların temel özellikleri ise Tablo 4'de verilmiştir.

\section{1. İncelenen Ana Konular, Parametreler ve İlgili Açıklamalar}

$\mathrm{Bu}$ çalışmada öncelikle incelenmesi düşünülen tüm konulara yönelik şablonlar oluşturulmuştur. $\mathrm{Bu}$ şablonlar için gerekli işlenmemiş veriler, veri tabanından Microsoft Excel programına aktarılmıştır. Bulgular kısmındaki grafiklerin oluşturulmasında kullanılan minimum süre 6 ay ve maksimum süre 8 yıldır. Ayrıca bir kısım destekleyici veriler İBB Otopark Ana Planı ve İBB Ulaşım Ana Planı'ndan alınmıştır. Ancak bu çalışmada verilen kullanıcı alışkanlıklarına yönelik değerler her iki planda da incelenmemiştir.

Tablo 3 - Analiz yapılan temel konular ve incelenen parametreler

\begin{tabular}{|c|c|c|}
\hline $\begin{array}{l}\text { İncelenen Ana } \\
\text { Konular }\end{array}$ & $\begin{array}{l}\text { Toplanan/Alınan } \\
\text { Veriler }\end{array}$ & Açıklama \\
\hline $\begin{array}{l}\text { Otoparklarda } \\
\text { uygulanan tarifeler }\end{array}$ & $\begin{array}{l}\text { - Süre ve tarife } \\
\text { çizelgeleri }\end{array}$ & $\begin{array}{l}\text { - Farklı özelliklerde Anadolu yakasından } 6 \text { ve Avrupa yakasından } \\
12 \text { farklı yol kenarı otoparklardaki tarife çizelgeleri incelenmiştir. }\end{array}$ \\
\hline $\begin{array}{l}\text { Yol kenarı } \\
\text { otoparkların } \\
\text { kullanımlarının } \\
\text { (saat, gün, ay, } \\
\text { mevsim ve yıl bazlı } \\
\text { olarak) incelenmesi }\end{array}$ & $\begin{array}{l}\text { - Park etme } \\
\text { süresinin \% dağılımı } \\
\text { - Toplam işlem } \\
\text { sayısı } \\
\text { - Ortalama park } \\
\text { etme süresi }\end{array}$ & $\begin{array}{l}\text { Yol kenarı otoparkların kullanımına yönelik olarak; saat, gün, ay, } \\
\text { mevsim ve yıllara göre otoparkların kullanımı incelenmiştir. } \\
\text { - Saat bazlı incelemede park etme süresi ve \% dağılımı 2015, } 2016 \\
\text { ve } 2017 \text { 'nin ilk altı aylık verilerinden incelenmiştir. } \\
\text { - Gün bazlı incelemede işlem sayısı ve park etme süresi değişimi } \\
2009 \text { ile } 2016 \text { yılı dahil } 8 \text { yıllık sürede incelenmiştir. } \\
\text { - Ay bazlı incelemede işlem sayısı ve park etme süresi değişimi } \\
2015 \text { ve } 2016 \text { yılı dikkate alınarak incelenmiştir. } \\
\text { - Mevsim bazlı incelemede işlem sayısı ve park etme süresi } \\
\text { değişimi } 5 \text { yıllık verilerinden incelenmiştir. Ayrıca aynı yıllar } \\
\text { arasında mevsim bazlı ortalama park süresi, zaman serisi analiziyle } \\
\text { incelenmiştir. } \\
\text { - Yıl bazlı incelemede ise işlem sayısı ve park etme süresi değişimi } \\
\text { 7,5 yıllık verilerinden incelenmiştir. }\end{array}$ \\
\hline $\begin{array}{l}\text { Otopark doluluk } \\
\text { oranlarının } \\
\text { incelenmesi }\end{array}$ & $\begin{array}{l}\text { - Yol kenarı otopark } \\
\text { kapasiteleri } \\
\text { - Saat bazlı kullanım } \\
\text { miktarı ve doluluk } \\
\text { oranları }(\%)\end{array}$ & $\begin{array}{l}\text { - Son } 2,5 \text { yıllık verilerden sabah } 08.00 \text { ile } 19.00 \text { saatleri arasında } \\
\text { İstanbul genelinde yol kenarı otoparkların kullanım miktarı ve } \\
\text { doluluk oranları (\%) incelenmiştir. Kritik doluluk oranının }(\% 85) \\
\text { aşıldığı saat/ler tespit edilmiştir. } \\
\text { - Yakalar arasında otoparklarda kalma süreleri hesaplanmıştır. }\end{array}$ \\
\hline $\begin{array}{l}\text { Otopark } \\
\text { ücretlerindeki } \\
\text { artışın etkisi }\end{array}$ & $\begin{array}{l}\text { - Nakit işlem sayısı } \\
\text { - Nakit park süresi } \\
\text { - } 0-15 \text { d ücretsiz işl. } \\
\text { - Tahakkuk-tahsilat } \\
\text { oranındaki } \\
\text { değişimler }\end{array}$ & $\begin{array}{l}\text { - Anadolu yakasında } 3 \text { ve Avrupa yakasında } 5 \text { farklı ilçeden, yol } \\
\text { kenarı otoparklar seçilmiştir. Bu otoparkların özellikleri Tablo 4'de } \\
\text { verilmiştir. } \\
\text { Ücret artış miktarları ve bu artışların kısa süreli etkisi, } 1 \text { ay öncesi } \\
\text { ve sonrası veri tabanından alınan ham verilerin işlenmesiyle analiz } \\
\text { edilmiştir. }\end{array}$ \\
\hline
\end{tabular}


Tablo 3 - Analiz yapllan temel konular ve incelenen parametreler (devam)

\begin{tabular}{|c|c|c|}
\hline $\begin{array}{l}\text { İncelenen Ana } \\
\text { Konular }\end{array}$ & $\begin{array}{c}\text { Toplanan/Alınan } \\
\text { Veriler }\end{array}$ & Açıklama \\
\hline $\begin{array}{l}\text { Kısa süreli ücretsiz } \\
\text { park } \\
\text { uygulamasının } \\
\text { etkisinin } \\
\text { incelenmesi }\end{array}$ & $\begin{array}{l}\text { - Devinim } \\
\text { - İşlem başı gelir } \\
\text { - Tahakkuk ve } \\
\text { tahsilat oranları, } \\
\text { - Genel tahsilat, } \\
\text { - Ortalama park } \\
\text { etme süreleri }\end{array}$ & 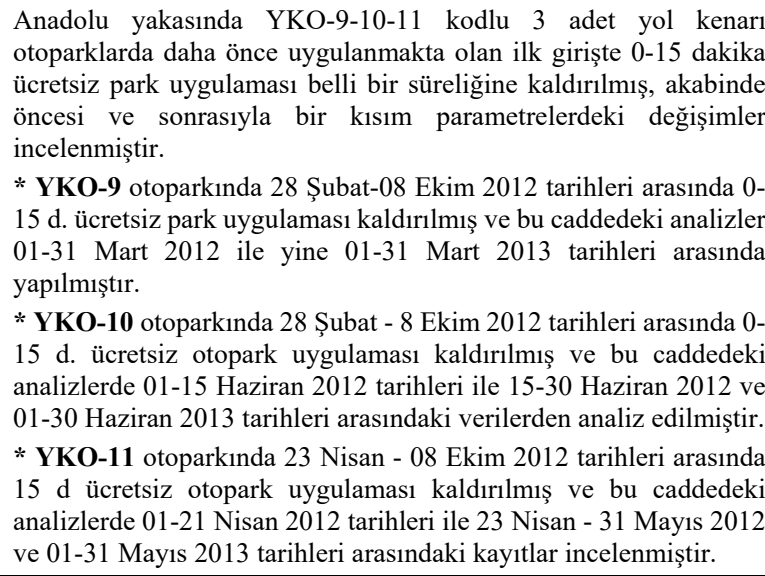 \\
\hline $\begin{array}{l}\text { İUAP'deki günlük } \\
\text { ortalama } \text { otopark } \\
\text { ücreti formülünün } \\
\text { incelenmesi }\end{array}$ & $\begin{array}{l}\text { - Günlük ortalama } \\
\text { park ücreti } \\
\text { - KBGSYH } \\
\text { - Otomobil sahipliği }\end{array}$ & $\begin{array}{l}\text { - İUAP'de verilmiş olan otopark ücretlendirme modeli Stata } 14 \\
\text { yazılım programı kullanılarak regresyon analiziyle incelenmiş ve } \\
\text { tutarsızlı̆̆ tespit edilmiştir. }\end{array}$ \\
\hline
\end{tabular}

Tablo 4 - İnceleme yapılan yol kenarı otoparkların bir kismının temel özellikleri [55]

\begin{tabular}{|l|l|c|c|c|c|c|c|}
\hline Parklar & \multicolumn{1}{|c|}{ İçe } & $\begin{array}{c}\text { Otopark } \\
\text { açılış tarihi }\end{array}$ & Kapasite & $\begin{array}{c}\text { Çalışma } \\
\text { saatleri }\end{array}$ & $\begin{array}{c}\text { Giriş } \\
\text { saati ve } \\
\text { ücreti } \\
(\mathrm{TL})^{1}\end{array}$ & Ara saatler ve ücreti (TL) & $\begin{array}{c}\text { Tam } \\
\text { gün } \\
\text { ücreti } \\
\text { (TL) }\end{array}$ \\
\hline YKO-1 & Ümraniye & 01.02 .2010 & 10 & $08.00-18.00$ & $0-1: 6$ & $1-2: 8 ; 2-4: 9 ; 4-8: 11$ & 14 \\
\hline YKO-2 & Kartal & 19.01 .2006 & 70 & $08.30-18.30$ & $0-2: 7$ & $2-4: 8 ; 4-6: 9 ; 6-8: 10$ & 12 \\
\hline YKO-3 & Kartal & 28.11 .2014 & 70 & $09.00-18.00$ & $0-1: 7$ & $1-2: 8 ; 2-4: 9 ; 4-6: 10 ; 6-8:$ & 12 \\
\hline YKO-4 & Sarıyer & 07.07 .2006 & 16 & $09.00-19.00$ & $0-1: 7$ & $1-2: 8 ; 2-4: 10 ; 4-8: 13$ & 15 \\
\hline YKO-5 & Şşlli & 21.03 .2007 & 38 & $09.00-19.00$ & $0-1: 8$ & $1-2: 10 ; 2-4: 14 ; 4-8: 18$ & 20 \\
\hline YKO-6 & Bakırköy & 01.11 .2007 & 19 & $09.00-18.00$ & $0-1: 7$ & $1-2: 8 ; 2-4: 9 ; 4-8: 11$ & 14 \\
\hline YKO-7 & Bayrampaşa & 09.10 .2008 & 60 & $08.30-18.00$ & $0-1: 7$ & $1-2: 8 ; 2-4: 9 ; 4-8: 11$ & 14 \\
\hline YKO-8 & Avcılar & 13.05 .2009 & 58 & $09.00-17.30$ & $0-1: 7$ & $1-2: 8 ; 2-4: 9 ; 4-8: 11$ & 13 \\
\hline YKO-9 & Üsküdar & 11.05 .2006 & 103 & $09.00-18.00$ & $0-1: 7$ & $1-2: 8,2-4: 10 ; 4-8: 13$ & 15 \\
\hline YKO-10 & Ataşehir & 11.07 .2006 & 265 & $09.00-18.00$ & $0-1: 7$ & $1-2: 8 ; 2-4: 9 ; 4-8: 11$ & 14 \\
\hline YKO-11 & Pendik & 19.01 .2010 & 45 & $09.00-19.00$ & $0-1: 7$ & $1-2: 8 ; 2-4: 10 ; 4-8: 11$ & 13 \\
\hline
\end{tabular}

\footnotetext{
${ }^{1} 6,7$ ve 8 TL'lik ilk dilim (giriş) ücretleri, İSPARK tarafindan yürütülen yol kenarı ücretlendirmenin \%81'ini temsil etmektedir.
} 


\subsection{Analiz Yapılan Otoparkların Temel Özellikleri}

Parkların ücret artış miktarları ve bu artışların 1 ay öncesi ve sonrası; ortalama işlem sayısı, ortalama park süreleri, 15 dakika girişler, tahakkuk ve tahsilat miktarlarındaki değişimleri incelemek üzere Anadolu yakasından 3 (YKO 1-3) ve Avrupa yakasında 5 farklı ilçede (YKO 4-8) işletilmekte olan yol kenarı otoparklar seçilmiştir. Tablo 4'de analizi yapılan otoparkların temel özellikleri verilmiştir.

\subsection{Fiyat Tarife Değişiklikleri ve Günlük Otopark Ücretleri}

$\mathrm{Bu}$ çalışmada ilçesine ve ilçedeki konumuna göre Anadolu yakasından 6 ve Avrupa yakasından 12 farklı lokasyonlardaki ücret tarifleri incelenmiştir. Anadolu yakasındaki, 5 otoparkın giriş ücreti 0-1 saat 7 TL ile başlayarak, günlük minimum 12 TL ve maksimum 15 TL ücrete kadar çıkabilmektedir. Diğer otoparkta ise giriş ücreti 0-2 saat 7 TL ile başlamakta ve günlük 12 TL ücret alınmaktadır. Aynı durum için Avrupa yakası incelendiğinde 0-1 saat giriş ücreti 9 lokasyonda 7 TL ve 3 lokasyonda 8 TL olarak başlamakta ve günlük ücret 13 TL ile 20 TL arasında değişebilmektedir. Ara saatlerdeki değişim Tablo 4'den incelenebilir. Özdeş fiyatlandırmalardan dolayı Avrupa yakasındaki 7 otoparka tabloda yer verilmemiştir.

\section{BULGULAR}

Yol kenarı otoparkların kullanımına yönelik olarak; saat, gün, ay, mevsim ve yıllara göre incelemeler yapılmıştır. Ayrıca mevsim bazlı ortalama park süresi zaman serisiyle incelenmiş, otoparkların doluluk oranları, ücret artışının ve kısa süreli ücretsiz park uygulamalarının devinim ve tahakkuk-tahsilat oranını nasıl etkilediği değerlendirilmiştir. Bir diğer konuda yol kenarı ve yol dışı otoparklarda uygulanmakta olan ücretlendirme yaklaşımı ve ücretlendirmenin temel bileşenleri ile İUAP'de verilmiş olan otopark ücretlendirme modeli Stata 14 yazılım programı kullanılarak regresyon analiziyle incelenmiş ve tutarsızlığı tespit edilmiştir.

\subsection{Otoparkların Kullanımı ile İlgili Analizler}

Saat bazlı inceleme: Şekil 2'de bir yıllık verilerden ortalama bir günlük otopark doluluk oranlarının saat bazlı dağılımı 5.533.616 işlem üzerinden incelenmiştir. Bu incelemede yol kenarı otoparklara en yoğun giriş \%14 oranıyla sabah saat 09.00 ile 10.00 arasında, ayrıca 09.00 ile 12.00 saatleri arasında ise \%35'lik toplam giriş olmuştur. Yaz mevsiminde ise 19.00-24.00 saatleri arasındaki hem otopark kullanım kapasitelerinde hem de ortalama park sürelerinde artış olduğu da tespit edilmiştir.

Gün bazlı inceleme: Gün içerisinde park etme davranışları zaman ve mekânda farklılıklar göstermektedir. Birçok aktivite hafta sonuna geçiş ile hafta sonu tatiline girmekte, dolayısı ile hafta içi gözlemlendiği şekli ile gündüz parklanmalarının azalmasına katkıda bulunmaktadır. Buna karşın farklı mahallerde gündüz parklanmasının yoğunlaşmasına neden olmaktadır. Yıl içerisinde yaz-kış döngüsü okulların tatil olması, yaz aylarında şehir dışına çıkılmasının sıklaşması nedenleri ile parklanmaların azalmasına neden olmaktadır. Gündüz ve ara parklanmaların zaman ve mekânda mevsimlere göre hafta sonlarında değişkenliğinin 
ortaya çıkardığı park alan sunumunun talep değişkenliğine uyumlu olarak esnek olmasını desteklemektedir [35].

15.191.262 yol kenarı otopark işlemi verileri baz alınarak, günler arasındaki değişim Şekil 3'de gösterilmiştir. Bu grafik incelendiğinde en fazla işlemin haftanın orta günü olan Çarşamba gününde ve en az işlemin de Pazar gününde gerçekleştiği; ayrıca otoparklarda ortalama kalma süresinin Pazar günlerinde diğer günlerden yaklaşık 20 dakika daha uzun olduğu da tespit edilmiştir. Yol kenarlarında ortalama parkta kalma süresi yaklaşı 120 dakikadır. Yapılan bir anket çalı̧̧masında sürücülere "Otopark yeri bulmada en çok zorlandlklarl gün?" sorulmuş; bu soruya \%31,5'1 Cumartesi, \%22'si Pazartesi, \%20,3'ü Pazar ve \%19,4'ü Cuma günü cevabını vermiştir [47]. Bu cevaplar, Şekil 3'deki verilerle belli düzeyde çelişmektedir.

Ay bazlt inceleme: Şekil 4'de 2015 ve 2016 yıllarına ait 27.658.406 işlem dikkate alınmıştır. En çok işlem her iki yılda da Mart ayında ve en az işlem ise 2015 yılı Şubat ayı ile 2016 yılında ise sırasıyla başta Temmuz ayı olmak üzere Ağustos ve Eylül aylarında gerçekleşmiştir. $\mathrm{Bu}$ aylardaki otopark işlem sayısındaki keskin düşüşlerde, 15 Temmuz kalkışma/darbe girişiminin etkisi sebep olmuştur. Ortalama park etme süresi 2015 yılı Mayıs ve 2016 yılı Nisan ayında maksimum iken; en az ortalama park etme süresi ise 2015 yllı Ocak ayında 116 dakika ve 2016 yilında ise Şubat ayında 118 dakika olarak gerçekleşmiştir (Şekil 4). Ayrıca otoparkta kalma süreleri açısından aylar arasındaki sapma 2015 yılında maksimum 7, 2016 yılında ise 6 dakikadır.

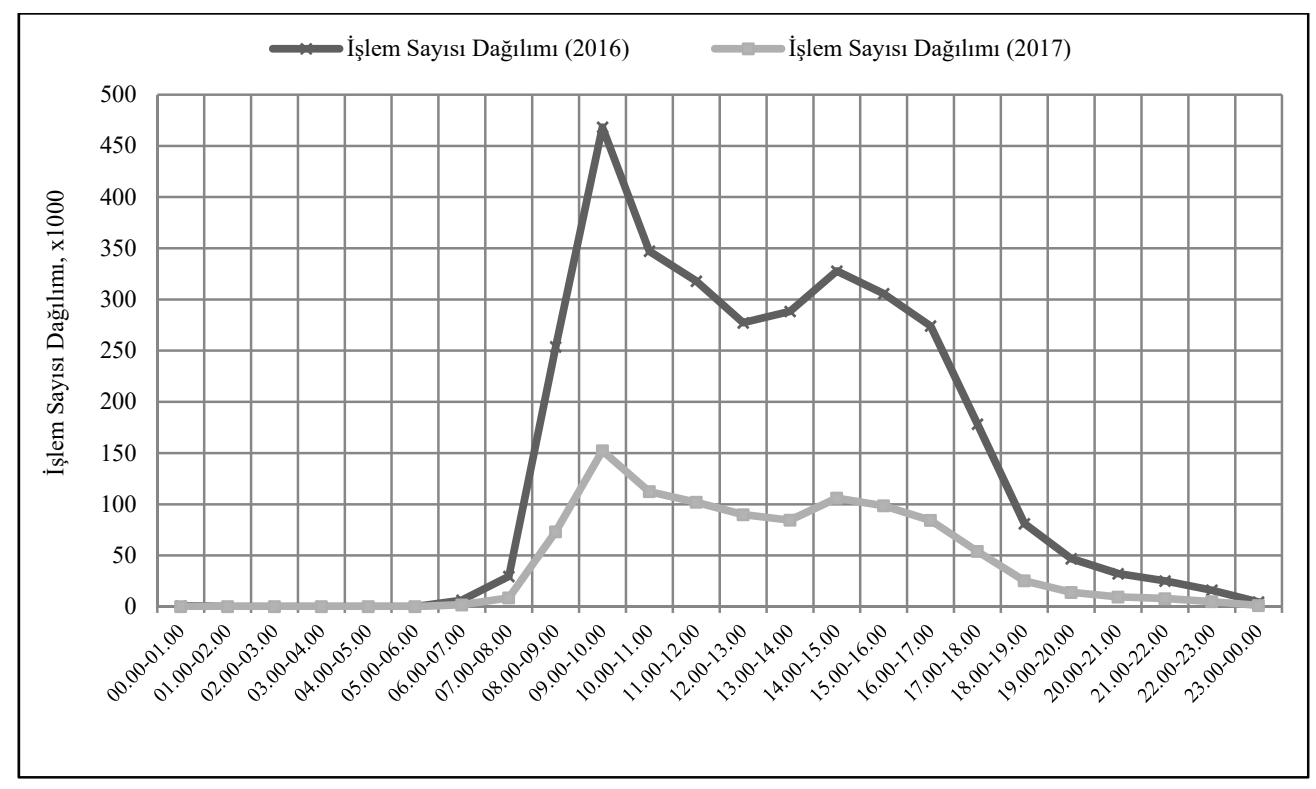

Şekil 2 - Saat bazll yol kenarı parklardaki işlem sayısı dağılımı 


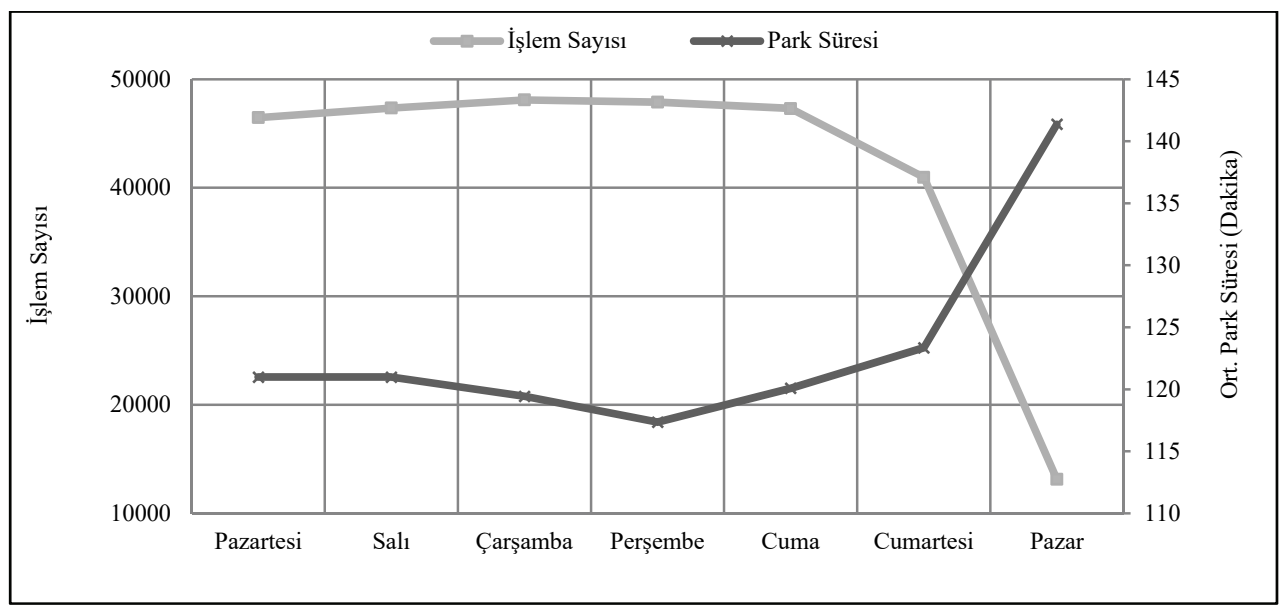

Şekil 3 - 2009-2016 yılları arasında tüm otoparklarda gün bazlı ortalama işlem sayısı ve park etme sürelerinin değişimi

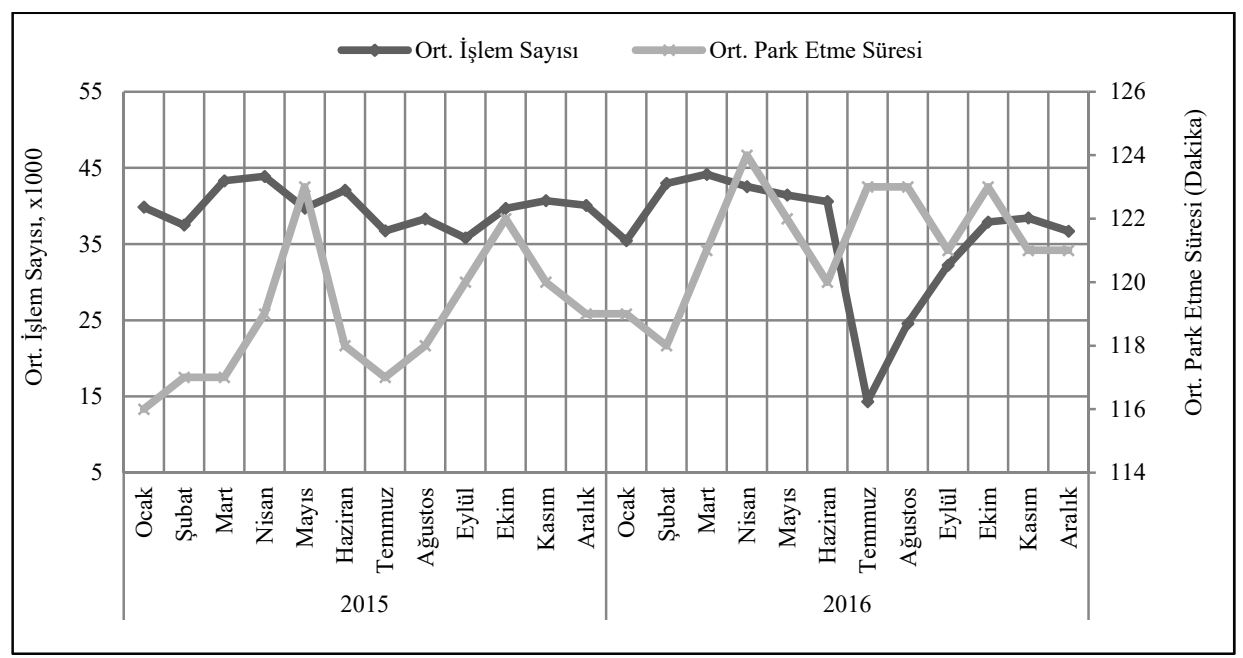

Şekil 4 - 2016 yılı ay bazlı işlem sayısı ve ortalama park etme sürelerinin değişimi

Yıllara göre mevsim bazlı inceleme: Şekil 5'de 2013-2016 yılları arası mevsim bazlı incelemede toplam 58.679.693 işlem üzerinden park sayısı ve ortalama park etme süreleri tespit edilmiştir. İşlem sayısı açısından en yüksek değerler ilkbahar mevsiminde olmuştur. 2016 yılı yaz mevsiminde işlem düşüklüğündeki belirginlikte kalkışmanın etkisi belirleyici olmuştur. Otoparklarda kalma süreleri yıllar geçtikçe artmış ve 2 saat sınırına gelmiştir. Ayrıca mevsimler arası sapma 2013 yılında 7 dakika, 2014 yılında 5 dakika, 2015 ve 2016 yılında ise 3 dakika olarak tespit edilmiştir. Ayrıca 2013-2017 yılları arasındaki mevsim bazlı ortalama park süresi, zaman serisi analizinde incelenmiştir. 2018 yılı için yapılan tahminde 
ortalama otoparkta kalma süresinin yaklaşı tüm mevsimlerde $\% 1,8$ düzeyinde yani yaklaşık 2,2 dakika artış göstereceği tespit edilmiştir. Bu incelemenin verileri ekte verilmiş olan Tablo E1'den incelenebilir ve grafiği Şekil E1'den görülebilir.

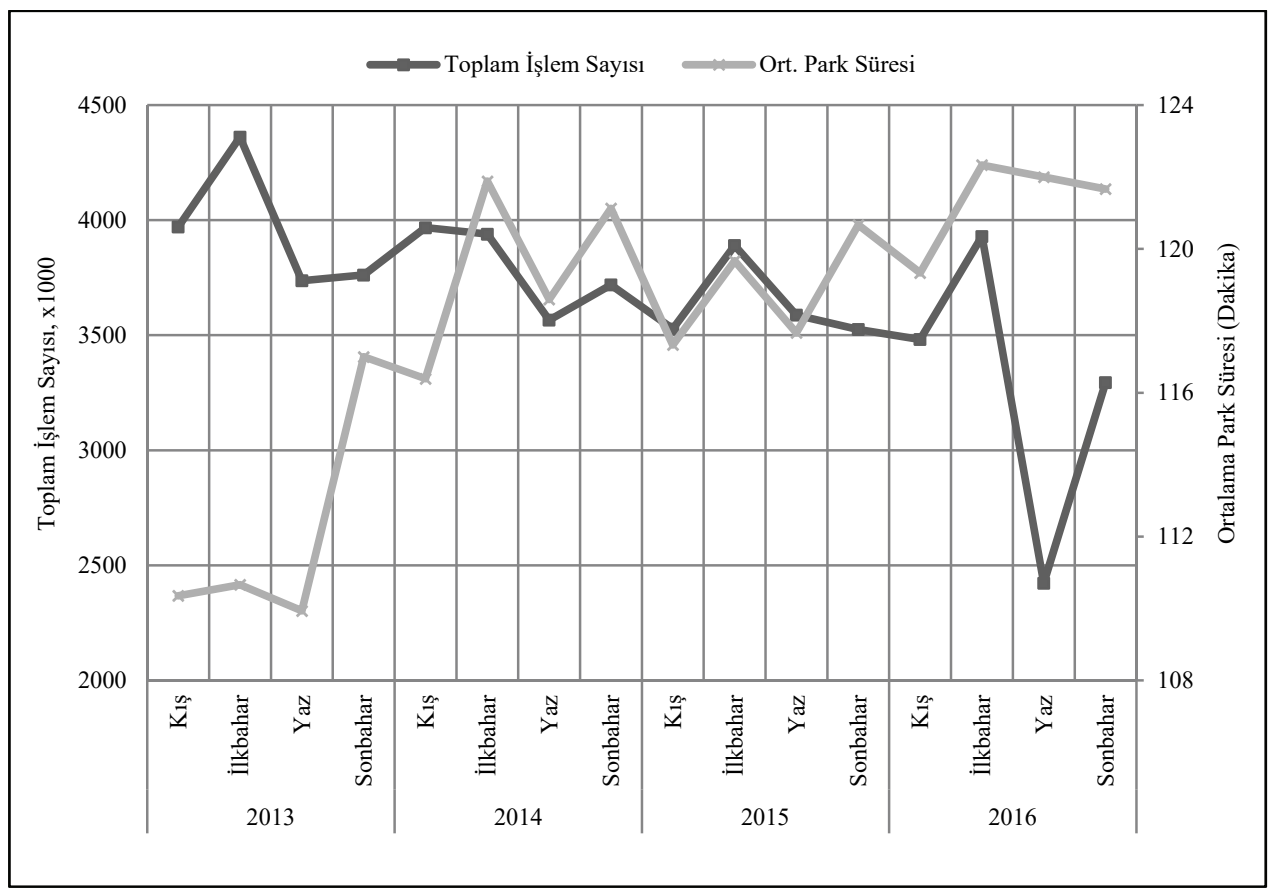

Şekil 5 - 2013-2016 yılları arasında mevsim bazlı yol kenarı otoparklarda işlem sayısı ve park etme sürelerinin değişimi

Yll bazll inceleme: 2010-2017 y1lları arasında, toplam 104.550.480 otopark işlemi üzerinden inceleme yapılmıştır. Şekil 6 incelendiğinde yıllar geçtikçe ortalama park süresinde artma olduğu görülmektedir. $\mathrm{Bu}$ artışın iyi irdelenmesi gerekmektedir. Bu durum "yol kenarl otoparkları kısa süreli park alanı olarak tanımlayan bir yönetim” açısından özendirici politikaların geliştirilmesi ve uygulanmasında yeterince etkili olunamadığını göstermektedir. Şekil 8'den de görüleceği üzere giriş ücretlerinin yüksek tutulması bu durumun nedenlerinden biridir. Eklerde verilen Tablo E2'den 2010 ve 2017 yılındaki günlük ortalama otopark ücretinde ciddi bir değişiklik olmazken, ilk dilim ücretinde hem süre azaltılmış hem de ücret keskin bir şekilde arttırılmıştır. Özellikle uygulanmakta olan fiyat-süre düzenlemeleri ile fiziksel kısıtlama üzerinde ciddiyetle durulması gereken hususlardandır. Ayrıca işlem sayısının ilk yıllarda artması ve sonraki yıllarda düşmeye başlaması bazı yol kenarı otoparkların acil ulaşım yolu olarak düzenlemesinden kaynaklanmaktadır. Grafikte 2017 yılının düşük park işlem değeri, ilk 6 aylık işlem miktarının gösterilmesinden kaynaklanmıştır. 


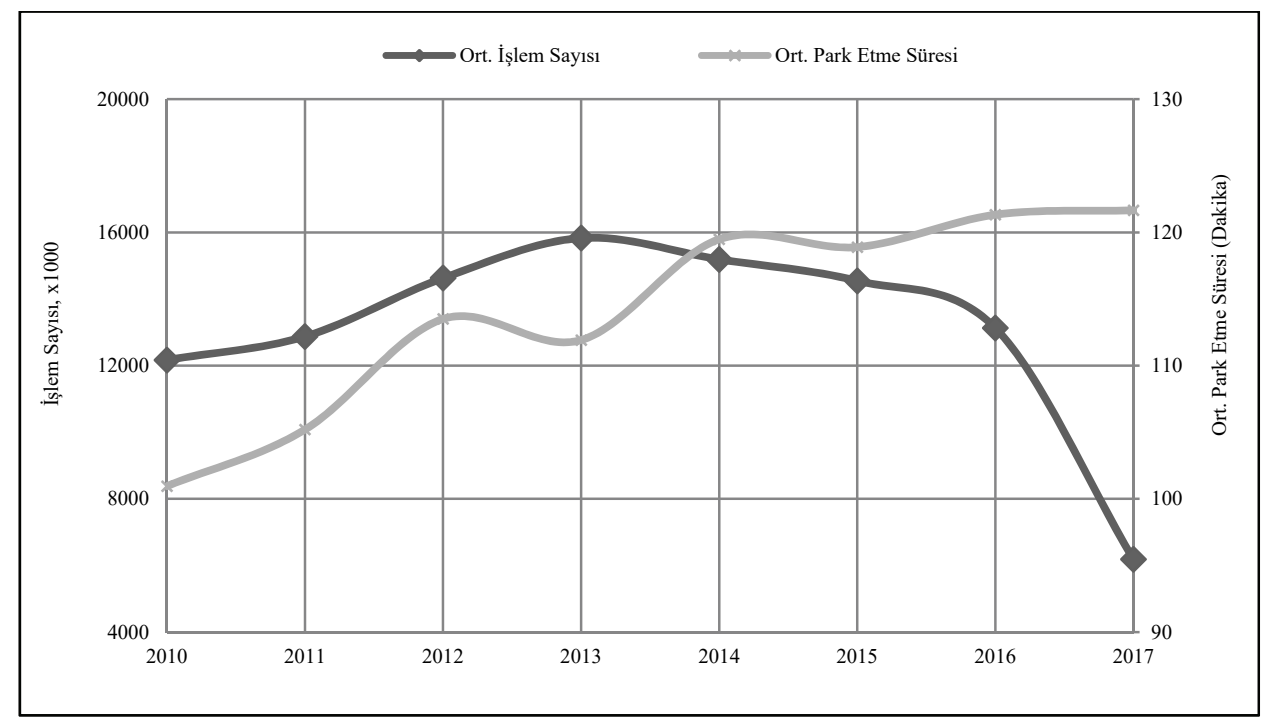

Şekil 6 - 2010-2017 yılları arasında yıllık işlem sayısı ve parkta kalma sürelerinin değişimi

\subsection{Doluluk Oranı Değişimlerinin İncelenmesi}

Şekil 7'den görüldüğü üzere saat bazlı son 2,5 yılın ortalaması dikkate alındığında Anadolu yakasında maksimum doluluk oranına \%57 ile 14.00-15.00 saatleri arasında; Avrupa yakasında ise yine aynı saatler arasında \%86 doluluk oranına erişilmektedir. Ayrıca yine aynı yakada 12.00-16.00 saatleri arasındaki doluluk oranı \%80'i aşmaktadır. Doluluk oranı \%80'nin üzerinde olan lokasyonlarda yönetim açısından ciddi bir şekilde durulması gerekmektedir. Irmscher (2015) tarafindan hazırlanan “Otopark Tasarımı” eserinde yol boyunca yer alan park alanlarının tipik günlük kapasite oranlarının verildiği grafikte; kısa süreli park etme saat 17.00 'de maksimum değerine (\%100) ve aynı saatte konut park etme oranı ise \%85 düzeylerine ulaşmaktadır. Gün içerisinde park etme düzeyi yaklaşı \%65 ile saat 15.00 'de gerçekleşmektedir [60].

\section{3. Ücret Artışının Park Etme Davranışına Etkileri}

Şehir merkezleri ve kullanım çeşitlilikleri, çalışanlar ve müşteriler açısından park baskısı oluşturabilir. Geneli memnun etmek için değil merkezin canlılığını ve yaşam kalitesini korumak için park politikaları oluşturulmalıdır. Merkezi alanlarda genel otopark kapasitesini arttırmamak, süre kısıtlamaları, yüksek otopark ücretleriyle uygulanabilir. Toplu taşıma araçları taleplerinin bir bölümünün değişmesini sağlamak için toplu taşıma seçenekleri ne kadar daha uygun bir hale getirilirse, zaten kısıtlı sayıda ve yüksek ücretli olan otoparklara gereksinim de aynı oranda düşecektir [35].

Anadolu yakasından 3 farklı (YKO 1-3) ve Avrupa yakasında 5 farklı ilçede (YKO 4-8) işletilmekte olan yol kenarı parkların ücret artış miktarları ve bu artışların 1 ay öncesi ve sonrası ortalama işlem sayısı, ortalama park süreleri, 15 dakika girişler, tahakkuk ve tahsilat 
miktarlarındaki değişimler incelenmiştir. Ücret artışları, otoparkların tam günlük değeri korunarak, giriş ücretlerinin $1 \mathrm{TL}$ arttırılmasıyla ve ara saatlerde çok az düzenlemeler yapılarak uygulanmıştır. 8 otoparkın ilk giriş ücretlerine toplamda yaklaşı \% 11 'lik yapılan zamla, otoparkları kullanan araç sayısında \%2,5 azalma, aynı otoparkların \%75'inde devinimde düşme ve toplam devinimde ise $\% 7$ düzeyinde azalma olduğu tespit edilmiştir. $\mathrm{Bu}$ durum ekte verilen Tablo E3'den incelenebilir. Ayrıca YKO-2 otoparkı hariç tüm otoparklarda nakit olarak park süresinde ortalama 5,5 dakika ve 0-15 d ücretsiz giriş yapan araç oranında da ortalama \%24 oranında azalma olmuştur. Ancak nakit park süresindeki düşme, ücret artışının müşteride geçici bir süre ürkeklik oluşturmasıyla yorumlanabilir. Çünkü müşteri ilk giriş ücretini peşin ödediğinden ücret artışının diğer zamanlara da yayılmış olacağı öngörüsünden hareketle parklanmayı daha hızlı sonlandırmak istemiş̧tir. Diğer parametreler için anlamlı ilişki kurulamamıştır.

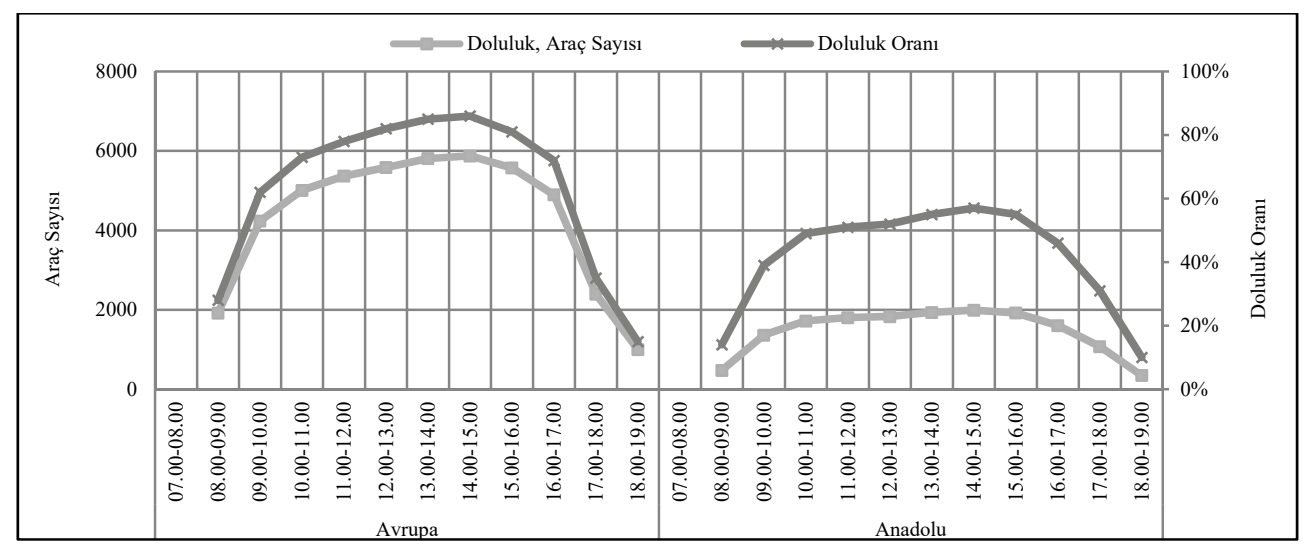

Şekil 7 - Anadolu ve Avrupa yakası saat bazlı doluluk oranı değissimi (son 2,5 yıllık veri)

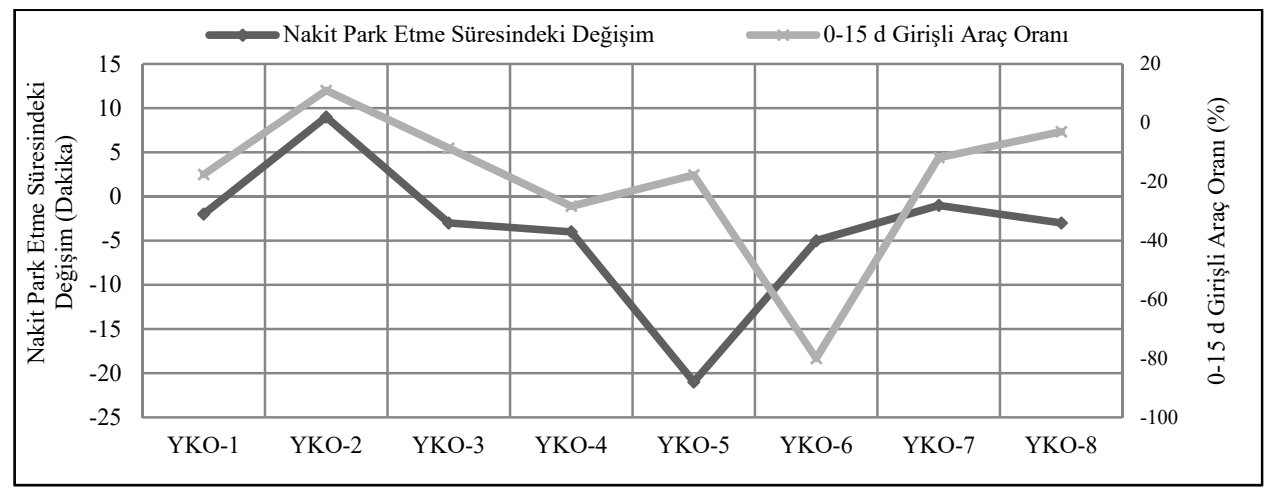

Şekil 8 - Yol kenarı otoparklardaki ücret artışının park etme süresi ve 0-15 dakika girişli araç oranına etkisi 


\subsection{Kısa Süreli Ücretsiz Park Uygulamasının İncelenmesi}

Şekil 9 ve 10'da Anadolu yakasında üç farklı ilçede bulunan YKO-9-10-11 kodlarıyla tanımlanmış olan yol kenarı otoparklarda uygulanan 15 dakika ücretsiz otopark uygulaması bir yıldan az olmayan bir süre uygulandıktan sonra, en az 5 ay kaldırılıp, daha sonra tekrar ilk uygulamaya dönülmüștür. Bu geçici uygulamada; devinim, işlem başı gelir, tahakkuk ve tahsilat oranları, genel tahsilat ve ortalama park etme sürelerindeki değişimler incelenmiş ve ortak tespitler aşağıda verilmiştir.

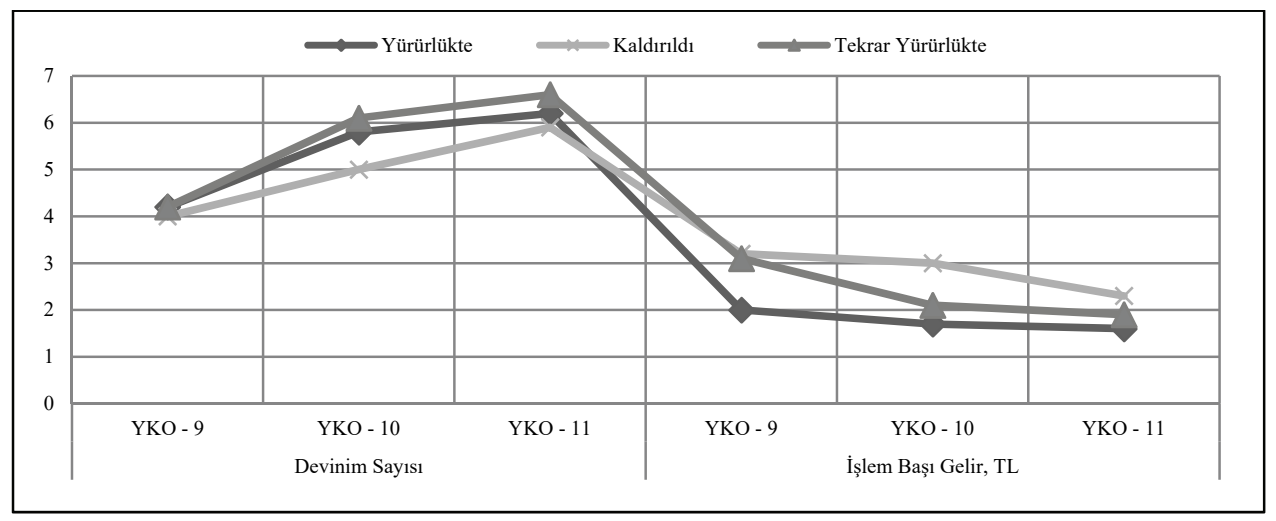

Şekil 9 - 0-15 dakika ücretsiz park uygulamasinin devinim ve işlem saylsına etkisi

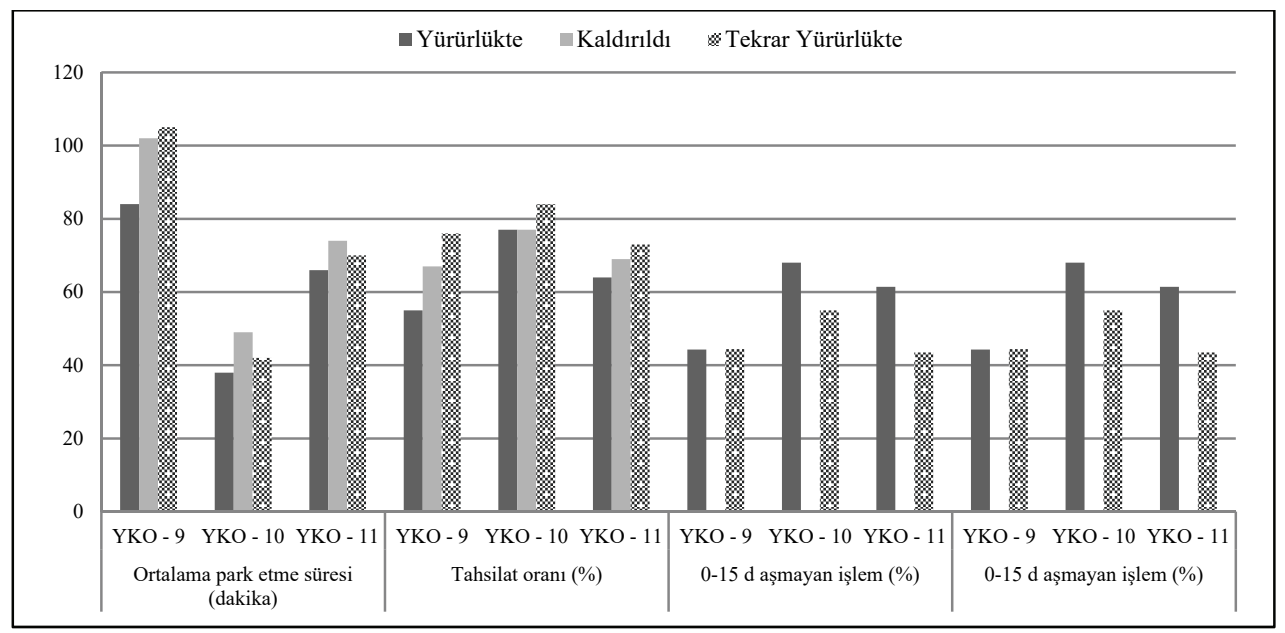

Şekil 10 - 0-15 d ücretsiz park uygulamasının park süresi, tahsilat oranı, işlem sayısına etkisi

15 dakika ücretsiz park uygulamasının geçici bir süre kaldırılmasıyla her üç otoparkta da;

- Devinimde en az \%4,8 ve en çok \%13,8 düşme (Şekil 9), 
- İşlem başı ortalama gelirde en az \%44 ve en çok \%76 artma (Şekil 9),

- Genel tahsilat oranında en az \%0 ve en çok \%21 artma (Şekil 9),

- Ortalama park etme süresinde en az \%12 (11 dakika) ve en çok \%21,5 (18 dakika) artma (Şekil 10) olmuş̧ur.

Bir diğer hususta 15 dakika ücretsiz park uygulamasının kaldırılmasıyla birlikte gerçekte kısa süreli park etme ihtiyacı bulunan araç sahiplerinin, 5-10 dakikalık park etmek için ücret ödemeyerek, park alanı içine tam parklanma yapmayarak ve/ya akan trafiğe engel oluşturacak şekilde araçlarını ikinci sıraya bırakarak parklanma yaptıkları, ayrıca bu araçların sürücüleri ile otopark personelleri arasında bazen tartışmalar yaşandığı da tespit edilmiştir.

15 dakika ücretsiz park uygulamasının geçici bir süre kaldırıldıktan sonra tekrar uygulamaya alınmasıyla her üç otoparkta da;

- Devinimde en az $\% 0$ ve en çok $\% 5$ artma,

- İşlem başı ortalama gelirde en az \%19 ve en çok \%55 artma,

- Genel tahsilat oranında en az \%9 ve en çok \%38 artma,

- Ortalama park etme süresinde en az \%6 ve en çok \%25 artma,

- Tahakkuk edip tahsil edilen ücret oranlarında en az \%8 ve en çok \%56 artma,

- 0-15 dakika kalmayı beyan ederek ücretsiz yararlananların oranında bir otopark hariç belirgin bir azalma olmuştur (Şekil 9-10).

\subsection{Park Etmede Süre Aşımı ve Ödeme Alışkanlığının İncelenmesi}

Yapılan incelemelerde yol kenarı otoparklardaki toplam işlem sayısının yaklaşık \%18'i 0-15 d ücretsiz seçeneği kullanılarak gerçekleştirilmektedir. Bu oranın \%33,7'si süre aşımı olmadan otoparktan çıkmıştır. \%41'i süre aşımı olmasına rağmen ücretini ödemiş ve \%24'ü ise süresini aştı̆̆ halde ödeme yapmadan çıkış yapmıştır. Ayrıca yapılan diğer tespitler şu şekildedir:

- $0-15 \mathrm{~d}$ ücretsiz seçeneğinden gerçekleşen girişlerin $\% 7,5^{\prime}$ lik dilimi $17.00-19.00$ saatleri arasında olmuştur. \%34'lük dilimi ise mesai saati bitimi olan 17.00-19.00 saatleri arasında çıkış yapmıştır.

- Anadolu yakasına göre Avrupa yakasındaki sürücülerin 0-15 dakika ücretsiz beyanlarına $\% 4$ daha sadakat göstermişlerdir.

- 0-15 d ücretsiz seçeneğinden gerçekleşen girişlerde süre aşımı olduğu halde ödeme yapmadan çıkış yapan araçların toplam işlem içerisindeki oranı yaklaşık \% $4,37^{\prime}$ dir.

- Son yıllarda 0-15 dakika ücretsiz girişlerde düşme ve aşan sürelerde ödeme alışkanlıklarında yükselme olmuştur. Bu durum müşterilerin zamanla İSPARK'1 ve dolayısıyla otopark işletmeciliğini daha çok benimsediklerine işaret etmektedir. 


\subsection{Yol Kenarı ve Yol Dışı Otoparklarda Ücretlendirme ${ }^{1}$}

Tablo 4 incelendiğinde bölgesine göre yol kenarı otoparklarda genellikle 0-1 saat giriş ücreti olarak 7 ile 8 TL ve kısmen de 0-2 saat girişte aynı ücretler uygulanabilmektedir. Sonraki ilave saatlerde genellikle 1 TL bazen de 2 TL gibi ücretler bir önceki tutara ilave edilmektedir. Günlük ücretler yaygın olarak minimum 12 TL ve maksimum 20 TL'dir. Günlük ücreti 20 TL olan otoparkların giriş ücreti 0-1 saat ve 8 TL olarak uygulanmaktadır. Yol kenarı otoparkların giriş ücreti, günlük ücretin minimum değerinin \%67'si, maksimum değerinin ise \%40'ıdır. Giriş ücretlerinin yüksekliğini anket sonuçları da doğrulamaktadır. Yapılan bir çalışmada sürücülerin \%84,4'ünün İSPARK otoparklarını pahalı bulduğu tespit edilmiştir [35]. Ayrıca son 7,5 yıllık veriler incelendiğinde yol kenarı otoparklarda kalma süresi ortalama 2 saatin altındadır. Son 2,5 yıllık veriler dikkate alındığında ise yol kenarı otoparklarda ortalama kalma süreleri Anadolu yakasında 93, Avrupa yakasında ise 115 dakikadır ${ }^{2}$. Aynı durum katlı otoparklarda sırasıyla 273 ve 412 dakika; açık otoparklarda 208 ve 161 dakika, park et-devam et uygulamasının yapıldığı otoparklarda ise 522 ve 469 dakika olarak tespit edilmiştir. Bir diğer hususta son 2,5 yıllık veriler dikkate alındığında ise günlük toplam yol kenarı park işleminin \%29'u, 3 saatten daha uzun süre park eden araçlara aittir. $\mathrm{Bu}$ duruma giriş ücretlerinin çok yüksek, ara ücretlerin düşük olması sebep olmuştur.

Yol kenarı otoparklarda ücretlendirme: Yol dışı otoparklara yönelik olarak örnek teşkil edecek ücretlendirme politikaları belirlenmiştir. Tablo E4'de verilen ücretler ve kullanım oranları toplam 15.256 araçlık yol kenarı otopark kapasitesinin tüm günlük ortalama park ücreti; yoğun bölgelerde 25 TL, orta yoğun bölgede 20 TL ve düşük yoğun bölgelerde ise 12 TL'dir. Aynı tablodan \%15'lik bir abone girişi ve aboneler hariç araçların \%18'inin ise 4 saatten daha fazla park ettiği tespit edilmiştir.

Yol dışı otoparklarda ücretlendirme: 6 farklı ilçede bulanan 3085 araç kapasiteli 9 katlı otoparkın günlük araç başına ücret ortalaması yaklaşık 12 TL olarak tespit edilmiştir. Devinim ortalaması 1,72'dir (Tablo E5). Tüm katlı otoparkların devinimi dikkate alındığında 0,88 civarındadır.

IUAP'deki otopark ücretlendirme modeli: İUAP'de 2010 y1l merkez alanda 1-3 saatlik park için ortalama 5 \$, 7-9 saatlik park için ise ortalama 10 \$ücret alınmakta olduğu belirtilmektedir. Günlük ortalama otopark ücreti ise 8,49 \$'dır. Otopark talep yönetimi açısından bugün kullanılan merkez alanlarda daha kısa süreli parklanma ve daha yüksek fiyat politikasından yararlanılarak merkez alanlarda otopark fiyatlandırmasının nasıl olacağı konusunda yapılan araştırmada 2023 yılı için üç farklı tahmin yapılmıştır. Buna göre hesaplanan değerler;

- $\% 3,2$ ortalama hane halk1 gelirine paralel büyüme ile 13,29 \$,

\footnotetext{
${ }^{1}$ İyi bir ücretlendirme politikasında şu hususların dikkate alınması gerekir: Sirkülasyon (devinim), kapasite, bölge, park etme karakteristiği, otopark tipi, mevcut tarife, alternatif otopark seçenekleri ve ücretleri, trafik üretimçekim verileri, aktif/atıl kapasite miktarı, taşma, esnaf, hane sakini ve abone sayıları ile park etme karakteristikleri, mevcut esnaf, ev sahibi ve abone ücretleri, toplu ulaşım imkanları, ev sahiplerine yönelik özgün uygulamalar (otopark harcı vs.) gibi hususlar dikkate alınarak tespit edilir.

${ }^{2}$ Sabah 08:00'den 19:00'a kadar olan son 2,5 yıllık yol kenarı otoparklarda araç başına ortalama park etme süresi Avrupa yakasında 115 dakika ve Anadolu yakasında ise 93 dakikadır. İki yakanın tam gün ortalaması 120 dakika olarak tespit edilmiştir.
} 
- \%5,2 GSYİH büyümesine paralel büyüme ile 17,26 \$ ve

- \%6,3 gelişmiş kentler regresyon modeli büyümesi ile 20,15 \$ şeklindedir [59].

Birinci yöntemde hane halkı gelirindeki \%3,2'lik artı̧a koşut bir büyüme ile 13,29 \$, ikinci yöntemde GSYİH büyümesine koşut büyüme ile $\% 5,2$ artış ile merkez alanda ortalama otopark ücretinin 17,26 \$ olacağı hesaplanmıştır. Üçüncü yöntemde ise Colliers International tarafından yapılmış dünya kentleri merkez alanları otopark fiyatlandırması çalışmasından yararlanılarak 2023 yılı İstanbul için merkez alanları fiyatlandırması yapılmıştır. Öncelikle dünya kentlerindeki otopark ücretlerinin özel araç sahipliği ve kişi başına düşen GSYH değerlerinden etkilenip etkilenmediği araştırılmıştır. Dünya genelinde 20 şehirden alınan, 1000 kişi başına düşen otomobil sayısı, kişi başı düşen GSYH ve günlük ortalama otopark ücretlerinden yararlanarak yapılan regresyon modellemesi sonucunda günlük otopark ücretindeki değişkenliğin \%92'sinin özel araç sahipliği ve kişi başına düşen gelir değişkenleri ile açıklanabildiği ortaya konmuştur. Bu çalışma sonucunda, otopark ücretinin hesaplanmasında kullanılacak formül aşağıdaki şekilde elde edilmiştir [59]:

\section{Günlük Ortalama Otopark Ücreti $=0,0015 * G S Y H-0,0436 *$ Otomobil Sahipliği}

Bu formül doğrultusunda İstanbul için 2023 yılı merkez alanı günlük ortalama otopark ücreti 20,15 \$ olarak hesaplanmıştır. Yukarıdaki üç değerlendirme sonucunda 2023 yılı otopark ücretlerinin ortalama 13 \$ ile 20 \$ arasında değiş̧ebileceği sonucuna varılmıştır [59].

Stata 14 yazılım programı kullanılarak yapılan regresyon analizi sonucunda IUAP'de verilmiş olan "Günlük Ortalama Otopark Ücreti $(\$)=0,0015^{*} \mathrm{KBGSYH}-0,0436^{*}$ Otomobil Sahipliği" formülünde sabit terimin dikkate alınmadığı tespit edilmiştir. Eklerde verilen Tablo E6'da sabit terimli ve sabit terimsiz regresyon analizlerinin sonuçları incelendiğinde sabit terimin istatistiksel olarak anlamlı olduğu ve bu nedenle modelde yer alması gerektiği saptanmıştır. Böylece model "Günlük Ortalama Otopark Ücreti (\$) $=46,7957+$ 0,0007*KBGSYH - 0,0839*Otomobil Sahipliği” olmalıdır. Sabit terimin dikkate alınmamas1 modelin tahminlerinde sapmaların ortaya çıkmasına neden olmaktadır. Sabit terim olmayan ve sabit terimli ifade de güncel değerler ${ }^{1}$ üzerinden günlük ortalama otopark ücreti hesaplandığında sırasıyla; 8,94 \$ ve 39,64 \$ bulunmaktadır. Günlük İstanbul'daki uygulanan ortalama değer ise 4,47 \$'dır. Ayrıca gözlem sayısının 20 ile sınırlı olması, tutarlı tahminler üretecek bir modelin elde edilmesinin önündeki en önemli engellerden biridir.

Yol kenarı ve yol dışı otoparklarda ücretlendirmenin temel bileşenleri: Otopark işletmelerinin ücretlendirme politikaları; karma kullanım, konut dışı ve konut alanındaki, düşük, orta ve yüksek yoğunluklu bölgelerdeki kamulaştırma maliyetleri de göz önünde bulundurularak toplam maliyetin hesaplanmasiyla tespit edilmelidir. ${ }^{2}$ İstanbul'da

\footnotetext{
${ }^{1}$ İstanbul için KBGSYIH, 11.134 \$ ve otomobil sahipliği ise 178/1000 kişi tespit edilmiştir.

${ }^{2}$ İstanbul'da yerleşimin dağılımı homojen yapıda olmadığı gibi yayılımda herhangi bir hiyerarşiden de söz edilemez. $\mathrm{Bu}$ farkl11ıkların temel sebebi yereldeki sosyo-ekonomik farklılıklardır. Otopark işletmesinde ve ücret yönetiminde; değişen park alanı ihtiyacı, ekonomik yapı ve işyerleri ile konutların dağılımından dolayı yerelde farklı otopark kullanım düzeyleri söz konusudur. Bir mahalle ile komşu mahalle arasında emlak değeri ve ortalama gelir ile ilgili önemli derecede farklılık olması muhtemeldir. Aynı tip otoparkın, farklı emlak değeri, yerleşim bölgesindeki gelir durumu, otomobil sahipliği ve farklı talep yoğunluğu gibi nedenlerden dolayı farklı ücretlendirmeye tabi olması söz konusudur. Bu temel parametreleri hem ücretlendirme hem de bölgeleme çalışmalarında dikkate almak gerekir.
} 
fiyatlandırma politikalarının sağlıklı yönetilebilmesi için aşağıdaki hususların ve/ya bulguların birlikte dikkate alınması gerekmektedir.

- Fiyatlandırmada ve işletmenin sürdürülebilirliğine yönelik olarak yol kenarı ve yol dışı otoparkların yönetimi ve hizmet kalitesinde; sosyo-ekonomik yapı, otopark talep düzeyi ve araç sahipliğine göre ayarlama/düzenleme yapılmalıdır.

- ISPARK'ın temel yaklaşımlarından biri yol dışı otopark imkanı varsa, yol kenarı otoparkları yol dışı otoparklardan daha yüksek ücretle işletmek suretiyle yol dişı otoparkları teşvik etmektir. Halihazırda İSPARK tarafından işletilen yol kenarı park ücretleri, yol dışı park ücretlerinin ortalama 1,2 katıdır. ${ }^{1}$ Ancak bu politika yol kenarı otoparklarda süre kısıtlamalarıyla da desteklenmelidir ${ }^{2}$. Bu yöndeki politikalar eksiktir. Bir başka hususta Tablo 4'den görüldüğü üzere otoparklarda uygulanan ara kademe ücretlerinin bilimsellikten uzak olmasıdır.

- Yol dışı otoparkların ücretlendirmelerinde kamu ve özel sektör otoparkları birlikte düşünülürse daha iyi sonuçlar elde edilebilir. Ancak burada çelişkili bir durum söz konusudur. İl şartlarında, arsa maliyetleri hariç diğer maliyet unsurları dikkate alınarak birim otopark alanı üretmek için yapılan ortalama yatırım miktarları otopark sistemlerine bağlı olarak 25.000 - 100.000 TL arasında değişkenlik göstermektedir ${ }^{3}$. Buna ek olarak bölgesel etkin otopark yönetimi yapılmaması ve emlak değerlerinden dolayı özel müteşebbisler katlı otopark yatırımlarından kaçınmaktadırlar ${ }^{4}$. Bu sorunun çözümüne yönelik şöyle bir politika geliştirilebilir: Farklı işletme bölgelerine göre ücreti daha düşük olan yol dışı otoparkların sübvanse edilebilmesi için yol kenarı otoparkların genel karından yararlanılabilir. Yol kenarındaki karın maksimize edilebilmesi için personele dayalı sistemden vazgeçilmelidir.

- Otoparkların giriş ve günlük ücret sınır değerlerinde temel parametre olarak devinim ${ }^{5}$ dikkate alınmaktadır. İSPARK tarafından işletilen tüm otoparklar kendi içerisinde düşünülerek devinim değeri tespit edilmiştir. $\mathrm{Bu}$ bağlamda devinim oranı, 1'in altındaysa düşük; 1 ile 3 arasında orta ve 3'ün üzerinde ise yüksek devinimli otopark olarak tanımlanmıştır. Otoparklardaki ortalama devinim oranları; yol kenarı otoparklarda, 3,1; yol dişı açık otoparklarda 1,7 ve kapalı otoparklarda ise 0,88 olarak hesaplanmıştır. Gelir-gider dengesi incelendiği zaman çoğunlukla, düşük ve orta devinimli otoparklar, kamu tarafından işletiliyorsa sübvanse edilmesi gerektiği de tespit edilmiştir.

\footnotetext{
${ }^{1} \mathrm{Bu}$ hesaplama İSPARK tarafından işletilen otoparklar için yapılmıştır. Ayrıca İSPARK'ın işlettiği otoparkların dışında kalan otoparklar için şu an bir senkronizasyonun yapılması pek mümkün görünmemektedir.

${ }^{2}$ Dünya uygulamalarında bu problem yol kenarı otoparklarda genel olarak süre sınırı ve ciddi fiyat artışlarıyla sağlanmaktadır.

${ }^{3} \mathrm{Bu}$ değer İSPARK'taki uygulamalardan elde edilmiştir. EPA, yeraltı otoparklardaki park alanı başına inşaat maliyetini, karma merkezi kentsel alanlarda 25.000 ila 50.000 Euro arasında belirtmektedir [61].

${ }^{4}$ Her işletme kendi ücret tarifesini kendi tayin etmektedir. Bazı otopark alanlarında ücretli yol kenarı otoparklar; yol dışı otoparklardan daha ucuz olabilmektedir. Hâlbuki araçları yol dışı otoparklara teşvik etmek için yol kenarı otoparklar daha pahalı olmalıdır. Ayrıca ücretsiz, düşük ücretli ya da denetimsiz yol kenarı parkların bölgesel otopark yönetimiyle kontrol edilmesi de gerekmektedir.

${ }^{5}$ Devinim; bir birimlik otopark alanını gün boyunca kullanan araç sayıdır.
} 
- Yol kenarı otoparklarda personeller 10 saat esasına göre çalışmakta ve kişi başına ortalama 19; katlı otoparklarda ise çift vardiya usulüyle 24 saat esasına göre çalışılmakta ve yaklaşık personel başına 71 kapasite düşmektedir. ${ }^{1}$

- Yol kenarı otoparklardaki ücret artışının yansımasında yakın bölgelerde daha cazip yol dışı otopark seçeneğinin bulunup bulunmaması da etkili olmaktadır.

- Yol kenarlarında yüksek ücretten düşük ücrete doğru bir fiyatlandırma politikası izlenmektedir. ${ }^{2}$ Yani ilk dilim ücretini ödeyenler için otoparkta kalmayı özendirici bir politika uygulanmaktadır. Ücret kademelerinin birçok bölge için 0-15 dakika ücretsiz uygulanması haricinde ilk 2 saate kadar 0,5 saat kademeleriyle yapılması gerekir. $\mathrm{Bu}$ durum otoparklarda kalma süresinin azalmasına ve doğal olarak otoparklardan daha fazla kullanıcının yararlanmasına olanak sağlar. Bir diğer hususta arama trafiğinin azaltılması da sağlanmış olur.

- Tahakkuk edip tahsil edilemeyen ücretler için yasal adımlar atılmalıdır. Bunun yapılması yol dışı için teşvik edici olacaktır.

- Yerine göre 3-4 saatlik park kısıtlarının uygulanması gerekir. UKOME kararıyla süreyi aşan araçlara günlük ücret uygulaması gerçekleştirilebilir ${ }^{3}$. Bu durum şu anda uygulanmamaktadır.

\section{SONUÇ VE ÖNERILLER}

İyi düzenlenen ve yönetilen yol kenarı park alanları; yerel ekonomiyi ve sosyal hayatı destekler, çevreyi korur, emniyeti sağlar, araçlı yolculukların toplu taşımaya yönlenmesine katkı sunar, mobilite ve şehir yönetimine (imar ve tesis açısından) belirgin faydalar sağlar. Bu çalışmada 2009 ve 2017 yılının ilk 6 ayı dahil toplam 8,5 yıllık bir veri incelemesi yapılarak aşă̆ıdaki neticelere ulaşılmıştır.

İSPARK tarafindan işletilen tüm yol kenarı otoparklarda yıllık verilerden ortalama bir günlük otopark doluluk oranlarının saat bazlı dağılımı 5.533.616 işlem üzerinden incelendiğinde; en yoğun giriş \%14 oranıyla sabah saat 09.00 ile 10.00 arasında olmuştur. Ayrıca toplam girişin \%35'lik dilimi ise 09.00 ile 12.00 saatleri arasında gerçekleşmiştir.

15.191.262 yol kenarı otopark işlemi verileri baz alınarak, günler arasındaki değişim incelenmiştir. Bu incelemede en fazla işlemin haftanın orta günü olan Çarşamba gününde ve en az işlemin de Pazar gününde gerçekleştĭgi; ayrıca otoparklarda ortalama kalma süresinin Pazar günlerinde diğer günlerden yaklaşı 20 dakika daha uzun olduğu da tespit edilmiştir. Yapılan bir anket çalışmasında sürücülere "Otopark yeri bulmada en çok zorlandıkları gün?” sorulmuş; bu soruya \%31,5'1 Cumartesi, \%22'si Pazartesi, \%20,3'ü Pazar ve \%19,4'ü Cuma günü cevabını vermiş̧ir [47]. Bu cevaplar, bu çalışmadaki verilerle belli düzeyde çelişmektedir.

\footnotetext{
1 Mevcut durumda yol kenarı otoparklar \%90 düzeyinde 11-12 saat esasına göre işletilmekte ve ücretlendirilmektedir. Yol dışı otoparkların ücretlendirilmesinde bu durum gözardı edilmemelidir.

${ }^{2}$ Yol kenarı otoparkların giriș ücreti, günlük ücretin minimum değerinin \%67'si, maksimum değerinin ise \%40'1dır.

${ }^{3}$ Şuanda yol kenarı park alanları kısa süreli park yeri olarak isimlendirilmekte ancak gün boyu park edilebilmektedir. Bu çelişkili bir durumdur.
} 
Ay bazlı incelemede 2015 ve 2016 yıllarına ait 27.658.406 işlem dikkate alınmıştır. En çok işlem her iki yılda da Mart ayında ve en az işlem ise 2015 yılı Şubat ayı ile 2016 yılında ise sırasıyla başta Temmuz ayı olmak üzere Ağustos ve Eylül aylarında gerçekleşmiştir. Bu aylardaki otopark işlem sayısındaki keskin düşüşlerde, 15 Temmuz kalkışma/darbe girişiminin etkisi olmuştur. Ortalama park etme süresi 2015 yılı Mayıs ve 2016 yılı Nisan ayında maksimum iken; en az ortalama park etme süresi ise 2015 yılı Ocak ayında 116 dakika ve 2016 yılında ise Şubat ayında 118 dakika olarak gerçekleşmiştir. Ayrıca otoparkta kalma süreleri açısından aylar arasındaki sapma 2015 yılında maksimum 7, 2016 yılında ise 6 dakikadır.

Y1llara göre mevsim bazlı incelemede 2013 - 2016 yılları arasındaki toplam 58.679.693 otopark işlem sayısı dikkate alınmıştır. İşlem sayısı açısından en yüksek değerler ilkbahar mevsiminde olmuştur. 2016 yılının yaz mevsimindeki işlem düşüklüğündeki belirginlikte kalkışmanın etkisi belirleyici olmuştur. Otoparklarda kalma süreleri yıllar geçtikçe artmış ve 2 saat sınırına gelmiştir. Ayrıca mevsimler arası sapma 2013 yılında 7 dakika, 2014 yılında 5 dakika, 2015 ve 2016 yılında ise 3 dakika olarak tespit edilmiştir. Ayrıca 2013-2017 yılları arasındaki mevsim bazlı ortalama park süresi, zaman serisi analiziyle incelenmiştir. 2018 yılı için yapılan tahminde ortalama parkta kalma süresinin yaklaşık tüm mevsimlerde \%1,8 düzeyinde yani yaklaşık 2,2 dakika artış göstereceği saptanmıştır. Bu incelemenin verileri Tablo E1'de verilmiş ve grafiği ise Şekil E1'de gösterilmiştir.

Yıl bazlı incelemede 2010 ve 2017 yılının ilk altı ayı (7,5 yıllık veriler) dahil toplam 104.550.480 otopark işlemi üzerinden bir tetkik yapılmıştır. Yıllar geçtikçe ortalama park süresinde artma olduğu görülmüştür. Bu artışın iyi irdelenmesi gerekmektedir. Bu durum “yol kenarı otoparkları kısa süreli park alanı olarak tanımlayan bir yönetim” açısından özendirici politikaların geliştirilmesi ve uygulanmasında yeterince etkili olunamadığını göstermektedir. Ayrıca işlem sayısının ilk yıllarda artması ve sonraki yıllarda düşmeye başlaması bazı yol kenarı otoparkların acil ulaşım yolu olarak düzenlemesinden kaynaklanmıştır.

Saat bazlı son 2,5 yılın ortalaması dikkate alındığında Anadolu yakasında maksimum doluluk oran $\% 57$ ile 14.00-15.00 saatleri arasında; Avrupa yakasında ise yine aynı saatler arasında \%86 doluluk oranına erişildiği tespit edilmiştir. Ayrıca yine aynı yakada 12.00-16.00 saatleri arasındaki doluluk oranı \%80'i aşmıştır. Doluluk oranı \%80'den fazla olan lokasyonlarda ücret-süre yönetim araçlarının yeniden dikkate alınması gerekmektedir.

Anadolu yakasından 3 farklı (YKO 1-3) ve Avrupa yakasında 5 farklı ilçede (YKO 4-8) işletilmekte olan yol kenarı parkların ücret artış miktarları ve bu artışların 1 ay öncesi ve sonrası ortalama işlem sayısı, ortalama park süreleri, 15 dakika girişler, tahakkuk ve tahsilat miktarlarındaki değişimler incelenmiştir. Ücret artışları, otoparkların tam günlük değeri korunarak, giriş ücretlerinin $1 \mathrm{TL}$ arttırılmasıyla ve ara saatlerde çok az düzenlemeler yapılarak uygulanmıştır. 8 otoparkın ilk giriş ücretlerine toplamda yaklaşık \%11'lik yapılan zamla, otoparkları kullanan araç sayısında \%2,5 azalma, aynı otoparkların \%75'inde devinimde düşme ve toplam devinimde ise $\% 7$ düzeyinde azalma olduğu tespit edilmiştir (Tablo E3). Ayrıca YKO-2 otoparkı hariç tüm otoparklarda nakit olarak park süresinde ortalama 5,5 dakika ve $0-15$ d ücretsiz giriş yapan araç oranında da ortalama \%24 oranında azalma olmuştur. Ancak nakit park süresindeki düşme, ücret artışının müşteride geçici bir süre ürkeklik oluşturmasıyla yorumlanabilir. Çünkü müşteri ilk giriş ücretini peşin 
ödediğinden ücret artışının diğer zamanlara da yayılmış olacağı öngörüsünden hareketle parklanmayı daha hızlı sonlandırmak istemiştir.

Anadolu yakasında üç farklı ilçede bulunan YKO-9-10-11 kodlarıyla tanımlanmış olan yol kenarı otoparklarda uygulanan 15 dakika ücretsiz otopark uygulaması bir yıldan az olmayan bir süre uygulandıktan sonra, en az 5 ay kaldırılıp, daha sonra tekrar ilk uygulamaya dönülmüştür. $\mathrm{Bu}$ uygulamadan şu tespitler yapılmıştır. 0-15 dakika ücretsiz park uygulamasının geçici bir süre kaldırılmasıvla her üç otoparkta da; devinimlerde en az $\% 4,8$ ve en çok \%13,8 düşme, işlem başı ortalama gelirde en az \%44 ve en çok \%76 artma, genel tahsilat oranında en az $\% 0$ ve en çok \%21 artma ile ortalama park etme süresinde en az \%12 (11 dakika) ve en çok \%21,5'lik (18 dakika) artma tespit edilmiştir.

0-15 dakika ücretsiz park uygulamasının kaldırılmasıyla birlikte gerçekte kısa süreli park etme ihtiyacı bulunan araç sahiplerinin, 5-10 dakikalık park etmek için ücret ödemeyerek, park alanı içine tam parklanma yapmayarak ve/ya akan trafiğe engel oluşturacak şekilde araçlarını ikinci sıraya bırakarak parklanma yaptıkları, ayrıca bu araçların sürücüleri ile otopark personelleri arasında bazen tartışmalar yaşandığı da tespit edilmiştir.

0-15 dakika ücretsiz park uygulamasının geçici bir süre kaldırıldıktan sonra tekrar uygulamava alınmasıvla her üç otoparkta da; devinimde en az $\% 0$ ve en çok $\% 5$, işlem başı ortalama gelirde en az $\% 19$ ve en çok $\% 55$, genel tahsilat oranında en az $\% 9$ ve en çok $\% 38$, ortalama park etme süresinde en az $\% 6$ ve en çok $\% 25$ ile tahakkuk edip tahsil edilen ücret oranlarında da en az \%8 ve en çok \%56 artma olmuştur. Ayrıca 0-15 dakika kalmayı beyan ederek ücretsiz yararlananların oranında bir otopark hariç belirgin bir azalma olmuştur.

Yapılan incelemelerde yol kenarı otoparklardaki toplam işlem sayısının yaklaşık \%18'i 0-15 d ücretsiz seçeneği kullanılarak gerçekleştirilmektedir. Bu oranın \%33,7'si süre aşımı olmadan otoparktan çıkmıştır. \%41'i süre aşımı olmasına rağmen ücretini ödemiş ve \%24'ü ise süresini aştı̆̆ halde ödeme yapmadan çıkış yapmıştır.

0-15 d ücretsiz seçeneğinden gerçekleşen girişlerin \%7,5'lik diliminin 17.00-19.00 saatleri arasında otoparka giriş yaptığı ve \%34'lük diliminin ise mesai saati bitimi olan 17.00-19.00 saatleri arasında çıkış yaptığı tespit edilmiştir.

0-15 d ücretsiz seçeneğinden gerçekleşen girişlerde süre aşımı olduğu halde ödeme yapmadan çıkış yapan araçların toplam işlem içerisindeki oranı yaklaşı $\% 4,37$ 'dir. Bir diğer hususta Anadolu yakasına göre Avrupa yakasındaki sürücülerin 0-15 d ücretsiz beyanlarına $\% 4$ daha sadakat gösterdikleri tespit edilmiştir.

Yol kenarı otoparklarda genellikle 0-1 saat giriş ücreti olarak 7 ile 8 TL ve kısmen de 0-2 saat girişte aynı ücretler uygulanabilmektedir. Sonraki ilave saatlerde genellikle 1 TL bazen de 2 TL gibi ücretler bir önceki tutara ilave edilmektedir. Günlük ücretler yaygın olarak minimum 12 TL ve maksimum 20 TL'dir. Günlük ücreti $20 \mathrm{TL}$ olan otoparkların giriş ücreti $0-1$ saat ve 8 TL olarak uygulanmaktadır. Yol kenarı otoparkların giriş ücreti, günlük ücretin minimum değerinin \%67'si, maksimum değerinin ise \%40'ıdır. Giriş ücretlerinin yüksekliğini anket sonuçları da doğrulamaktadır. Yapılan bir anket çalışmasında sürücülerin \%84,4'ünün İSPARK otoparklarını pahalı bulduğu belirtilmiştir.

Son 7,5 y1llık veriler incelendiğinde yol kenarı parklarda kalma süresi ortalama 2 saatin altındadır. Bir diğer hususta son 2,5 yıllık veriler baz alındığında ise günlük toplam yol kenarı 
park işleminin \%29'u, 3 saatten daha uzun süre park eden araçlara aittir. Bu duruma giriş ücretlerinin çok yüksek, ara ücretlerin düşük olmasina sebep olmuştur.

Son yıllarda 0-15 dakika ücretsiz girişlerde düşme ve aşan sürelerde ödeme alışkanlıklarında yükselme olmuştur. Bu durum müşterilerin zamanla İSPARK'1 ve dolayısıyla otopark işletmeciliğini daha çok benimsediklerine işaret etmektedir.

Yol kenarı otoparklarda tüm günlük ortalama park ücreti; yoğun bölgelerde 25 TL, orta yoğun bölgede 20 TL ve düşük yoğun bölgelerde ise 12 TL'dir.

Stata 14 yazılım programı kullanılarak yapılan regresyon analizi sonucunda İUAP'de verilmiş olan "Günlük Ortalama Otopark Ücreti $(\$)=0,0015^{*} \mathrm{KBGSYH}-0,0436^{*}$ Otomobil Sahipliği” formülünde sabit terimin dikkate alınmadığ tespit edilmiştir. Tablo E6'da sabit terimli ve sabit terimsiz regresyon analizlerinin sonuçları incelendiğinde sabit terimin istatistiksel olarak anlamlı olduğu ve bu nedenle modelde yer alması gerektiği saptanmıştır. Böylece model “Günlük Ortalama Otopark Ücreti (\$) = 46,7957 + 0,0007*KBGSYH 0,0839*Otomobil Sahipliği” olmalıdır. Sabit terimin dikkate alınmaması modelin tahminlerinde sapmaların ortaya çıkmasına neden olmaktadır. Sabit terim olmayan ve sabit terimli ifade de güncel değerler ${ }^{1}$ üzerinden günlük ortalama otopark ücreti hesaplandığında sirasiyla; 8,94 \$ ve 39,64 \$ bulunmaktadır. Günlük İstanbul'daki uygulanan ortalama değer ise 4,47 \$'dır. Ayrıca gözlem sayısının 20 ile sınırlı olması, tutarlı tahminler üretecek bir modelin elde edilmesinin önündeki en önemli engellerden biridir.

\section{Çalışma bağlamında sunulabilecek öneriler:}

Özel otomobil kullanımını azaltıcı önlemler olarak, raylı sistem ağının yaygınlaşması ile birlikte orta ve uzun vadede kademeli olarak, tüm yol kenarı otoparklarda düşük ücretten yüksek ücrete doğru bir fiyatlandırmanın benimsenmesi ve merkezi alanlardaki işyeri sahipleri hariç yol kenarı parkların 3 saat ile sınırlandırılması için gerekli stratejiler ve uygulamalar yapılmalıdır.

Yol kenarı otoparkları kısa süreli park alanı olarak tanımlayan bir yönetimin hem kısıtlayıcı hem de özendirici politikalar uygulayarak otoparklardan daha fazla müşterinin yararlanabilmesine olanak sağlaması gerekir.

Yol kenarı park ücretleri, otopark arayarak trafiği yavaşlatan araç sayısını azaltmak ve kaldırım alanlarının kullanımını iyileştirmek için düzenlenmelidir. Yakın gelecekte yol kenarı park ücretleri, talep duyarlılığına dayalı olarak dinamik bir şekilde ayarlanmak suretiyle daha verimli kullanılabilir.

Sürücülere otopark kullanım alışkanlığının kazandırılması ve parklanmanın ücret karşılığı bir hizmet olduğu anlayışının yerleştirilmesi için özendirici stratejiler geliştirilmelidir.

Otopark yönetmeliğinin taslak çalışmasının kamuoyu ile paylaşıldığı bu günlerde yol kenarı otopark düzenlemelerine ilişkin esasların net belirlenmesi ve yasal açıdan ihtilaflı hususların giderilmesi sağlanmalıdır.

\footnotetext{
${ }^{1}$ İstanbul için KBGSYH, 11.134 \$ ve otomobil sahipliği ise 178/1000 kişi tespit edilmiştir.
} 
Yol kenarı otoparklarda belediye adına işletmecilik yapan kuruluşlara denetim yetkisinin verilmesi gerekir.

Ücretsiz, düşük ücretli ya da denetimsiz yol kenarı parkların bölgesel otopark yönetimiyle kontrol edilmesi gerekir. Ayrıca otopark taleplerinin etkin ve verimli yönetilmesi için yol dışı ve yol kenarı otoparklarının bütünleşik olarak ücretlendirilmesi çok önemlidir.

Otopark \%80-85'in üzerindeki doluluğa ulaştığında fiyat-süre uygulamaları yeniden gözden geçirilmelidir.

Şehir merkezi ve ana ticaret aksları üzerindeki yol kenarı uzun süreli park işgallerinin kaldırılarak, kısa süreli parklanmalara dönüştürmek ve daha fazla araç için devinim elde etmek gerekir.

Özel aracı ile yolculuk edenlere; park yerleri, gerçek zamanlı doluluk boşluk oranları, ön rezervasyon, kurallar, ücretler ve seçenekler hakkında internet, SMS, telefon uygulamaları, sosyal medya kanalları, radyo-televizyon gibi mecralardan bilgilendirmeler yapılmalıdır.

Yol kenarı otoparkların büyük bir bölümünde denetimli işletmecilik yapılmadığından dolayı, vale park düzenleme esaslarının net bir şekilde belirlenmesi, denetimli ve kayıtlı bir sistem geliştirilmesi gerekir.

Araç işgali altındaki sokakların bir plan dahilinde parklanması, kullanıcı öncelikleri ve süre yönetimi ile park basıncının kontrollü yönetilmesi gerekmektedir.

Yol kenarı parklanma kurallarının ihlal edildiği durumların tanımlandığı, cezaların belirlendiği ve uygulama sürecini belirten bir bilgilendirme kılavuzunun hazırlanması gerekmektedir.

Otopark politikaları, sadece otopark ihtiyacı duyanların değil; etkileri ve sonuçları itibariyle herkesi ilgilendirdiğinden tüm topluma iyi anlatılmalı ve ortak bir anlayış oluşturulmalıdır. Anlayışın aktarımında "her türlü trafik oluşturanların bedelini ödemesi gerektiğine" özel vurgu yapılmalıdır. Bu yapılırken, iyi bir halkla ilişkiler çalışması ve tamamlayıcı otopark politikaları ile güvenin ve bağlılığın arttırılması da sağlanmalıdır.

Otoparklarda arz talep dengesinin bozulduğu zamanlarda, lokal stratejiler belirlenmelidir.

Sokakların ve yol kenarı otopark alanlarının engelli, yaşlı ve çocuklu aileler için güvenli, yayalar için konforlu ve bisiklet kullanıcıları için emniyetli olacak şekilde yeniden tasarlanmas1 gerekmektedir.

İnsana dayalı otopark işletmeciliğinin payı hızlı bir şekilde azaltılmalı ve başta EDS gibi denetim çözümleriyle desteklenen; mobil/SMS park, parkmetre gibi teknolojik ödeme araçlarının daha yaygın uygulanmasına geçilmelidir.

\section{Semboller}

$\begin{array}{ll}\text { EDS } & \text { : Elektronik Denetleme Sistemi } \\ \text { EPA } & : \text { Avrupa Park Endüstrisi - European Parking Association } \\ \text { GSYH } & : \text { Gayri Safi Yurtiçi Hasıla }\end{array}$




\author{
IBB $\quad$ : Istanbul Büyükşehir Belediyesi \\ IOAP $\quad$ : İstanbul Büyükşehir Belediyesi - İstanbul Otopark Ana Planı \\ ISPARK : Istanbul Otopark İsletmeleri Tic. AŞ \\ IUAP : İstanbul Metropoliten Alanı Kentsel Ulaşım Ana Planı \\ KBGSYH : Kişi Başına Gayri Safi Yurtiçi Hasıla \\ TÜIK : Türkiye İstatistik Kurumu \\ YDO : Yol Dlşl Otopark \\ YKO : Yol Kenarl Otopark
}

\title{
Teșekkür
}

Çalışmanın gerçekleştirilmesinde, veri desteği sağlayan başta İSPARK AŞ Genel Müdürü Sn. Nurettin Korkut'a, Genel Müdür Yardımcıları Sn. Samet Aslan ve Sn. Salih Selman Cebeci'ye, özellikle Anadolu Yakası İşletmeler Müdürü Sn. Mustafa Tüten ile Veri Analiz Uzmanı Sn. Yasin Ağırtmış’a teşekkürü bir borç bilirim.

\section{Kaynaklar}

[1] Okubay, M., Bölgesel Otopark Yönetimi ve Stratejileri: Tarihi Yarımada - Eminönü Bölgesi Örneği. YTÜ - Fen Bilimleri Enstitüsü - Yüksek Lisans Tezi, İstanbul, 2008.

[2] Barter, P.A., Off-Street Parking Policy without Parking Requirements: A Need for Market Fostering and Regulation. Transport Reviews, 30, 571-588, 2010.

[3] Asian Development Bank (ADB), Parking Policy in Asian Cities, Manila, 2011.

[4] Şenbil, M., Yetişkul, E., İstanbul için Gece Parklanma Davranışları Modellemesi. İMO Teknik Dergi, 2016 7515-7532, Yaz1 457, 2016.

[5] Külekçi, O., Ayözen, Y.E. ve İnaç, H., İstanbul Otopark Master Planı Çalışmaları. 4th International Transport and Vehicle Park Areas Management Symposium, CNR Expo, 27-28 May 2015.

[6] Karasay, T., Mekanik Otopark Tesislerinin Yer Seçimi ve Boyutlandırılması için Genetik Algoritma Tabanlı Bir Yaklaşım. İstanbul Teknik Üniversitesi - Fen Bilimleri Enstitüsü - Bilişim Anabilim Dalı - Mimari Tasarımda Bilişim Bilim Dalı, Yüksek Lisans Türkçe, 2016.

[7] Shoup, D., The High Cost of Free Parking, Chicago. American Planning Association, 2011.

[8] Victoria Transport Policy Institute - VTPI, Parking Management, Strategies for More Efficient Use of Parking Resources. Online TDM Encyclopedia, www.vtpi.org, 2015.

[9] Litman, T., Parking Management, Strategies, Evaluation and Planning. Victoria Transport Policy Institute (www.vtpi.org), 2013.

[10] Barhani, E. ve Ergün, G., Sürdürülebilir Otopark Stratejileri, 7. Ulaştırma Kongresi, İstanbul. TMMOB İnşaat Mühendisleri Odası, İstanbul Şubesi, 2007.

[11] Demir, A., Günümüzde ve Gelecekte Otomobil ve Otopark Trendi. 1. Kentiçi Ulaşımda Otopark Politikaları ve Uygulamaları Konferans1, 2009 
[12] Uzun, Ö.L., İstanbul'da Otopark Problemi. Marmara Üniversitesi Fen Bilimleri Enstitüsü Makine Eğitimi Anabilim Dalı, Yüksek Lisans Tezi, İstanbul, 2009.

[13] Stone, N., Chicago Ranks Third in The Nation for Parking Costs. Chicago Tribune, http://www.chicagotribune.com/news, 2017.

[14] Groote, J.D., Ommeren, J.V., Koster, H.R.A., Car Ownership and Residential Parking Subsidies: Evidence from Amsterdam. Economics of Transportation 6, 25-37, 2016.

[15] Euronews, The Cost of Parking across Europe - A Euronews Investigation. http://www.euronews.com, 10/05/2016, Erişim Tarihi: 14.08.2017

[16] Özen, M., Küçük Kentlerde Otopark Planlaması ve Yönetimi. Yıldız Teknik Üniversitesi Fen Bilimleri Enstitüsü, İnşaat Mühendisliği Anabilim Dalı - Ulaştırma Programı, Yüksek Lisans Tezi, İstanbul, 2014.

[17] Ommeren, J.V., The Economics of Parking: Experiences from the Netherlands. 3. Uluslararas1 Ulaşım ve Araç Park Alanları Yönetimi Sempozyumu Bildiri ve Sunum Kitabı, Intertraffic İstanbul - İstanbul Exibition Center, 0-31 May 2013.

[18] Barhani, E., Parking Management Strategies For Sustainable Transportation 'A Case Study For Istanbul'. Boğaziçi Üniversitesi Fen Bilimleri Enstitüsü - Yüksek Lisans Tezi, İstanbul, 2005.

[19] Uyur, E., Otopark Sorununun Arz ve Talep Temelinde İncelenmesine Yönelik Bir Araştırma: Kadıköy Merkez Örneği. Bahçeşehir Üniversitesi - Fen Bilimleri Enstitüsü - Kentsel Sistemler ve Ulaştırma Yönetimi, Yüksek Lisans Türkçe, 2015.

[20] Ison, S., 21st ACEA Parking Management Policy: Its Potential in Improving Urban Traffic Flows. Loughborough University, March 2014.

[21] Albert Gragera, A. ve Albalate, D., The Impact of Curbside Parking Regulation on Garage Demand. Transport Policy 47, 160-168, 2016.

[22] Concas, S., Nayak, N., A Meta-Analysis of Parking Price Elasticity. In: Proceedings of the TRB Annual Meeting, Washington, DC, 2012.

[23] Gillen, D.W., Estimation and Specification of The Effects of Parking Costs on Urban Transport Mode Choice. J. Urban Econ. 4, 186-199, 1977.

[24] Shoup, D.C., Wilson, R., Employer-Paid Parking: The Problem and Proposed Solutions. Transp. Q. 46, 169-196, 1992.

[25] Khodaii, A., Aflaki, E., Moradkhani, A., Modeling The Effect of Parking Fare on Personal Car Use. Trans. A: Civil Eng. 17, 209-216, 2010.

[26] Kobus, M.B.W., Guitiérrez-i-Puigarnau, E., Rietveld, P., Van Ommeren, J.N., The On-Street Parking Premium and Car Drivers' Choice between Street and Garage Parking. Reg. Sci. Urban Econ. 43, 395-403, 2013.

[27] Kelly, J.A., Clinch, J.P., Influence of Varied Parking Tariffs on Parking Occupancy Levels by Trip Purpose. Transp. Policy 13, 487-495, 2006.

[28] Simicevic, J., Milosavljeciv, N., Maletic, G., Kaplanovic, S., Defining Parking Price Based on Users' Attitudes. Transp. Policy 23, 70-78, 2012.

[29] Hess, D.B., The Effects of Free Parking on Commuter Mode Choice: Evidence from Travel Diary Data. Transp. Res. Rec. 1753, 35-42, 2001. 
[30] Weis, C., Vrtic, M., Widmer, P., Axhausen, K.W., Influence of Parking on Location and Mode Choice: A Stated Choice Survey. In: Proceedings of the 91st TRB Annual Meeting, Washington, DC, 2012.

[31] Tsamboulas, D.A., Parking Fare Thresholds - A Policy Tool. Transport Policy 8, 115-124, 2001.

[32] Simicevic, J., Vukanovic, S., Milosavljeciv, N., The Effect of Parking Charges and Time Limit to Car Usage and Parking Behaviour. Transp. Policy 30, 125-131, 2013.

[33] Gragera, A., The Economics of Parking: Essays on Regulation. Competition and Information Frictions, Universitat de Barcelona, http://diposit.ub.edu/dspace/handle/2445/118745, 2017.

[34] Barter, P., On-street Parking Management. SUTP, GİZ, 2016.

[35] İstanbul Büyükşehir Belediyesi (İBB), İstanbul Otopark Ana Planı - İOAP, 2016.

[36] Shoup, D., The High Cost of Free Parking. Planners Press (www.planning.org), 2005.

[37] Litman, T., Parking Pricing Implementation Guidelines How More Efficient Parking Pricing Can Help Solve Parking and Traffic Problems, Increase Revenue, and Achieve Other Planning Objectives. Victoria Transport Policy Institute, 2016.

[38] AT - Auckland Transport, AT Parking Strategy Document 2015.

[39] SFMTA, Demand-Responsive Parking Pricing Policies, On-Street Parking Meters and Off-Street Lots. San Francisco Municipal Transportation Agency, December 5, 2017.

[40] İnci, E., Kentte Parklanmanın Politikası. 3. Uluslararası Ulaşım ve Araç Park Alanları Yönetimi Sempozyumu Bildiri ve Sunum Kitabı, Intertraffic İstanbul - İstanbul Exibition Çenter, 0-31 May 2013.

[41] Palmer, D. ve Ferris, C., Parking Measures and Policies Research Review. Transport Research Laboratory, 27.05.2010

[42] Berg, N., Lots to Lose: How Cities Around The World Are Eliminating Car Parks. https://www.theguardian.com/cities/2016/sep/27/cities-eliminating-car-parks-parking, Tue 27 Sep 2016.

[43] Liu, Y., Wang, W. ve diğ., Metropolis Parking Problems and Management Planning Solutions for Traffic Operation Effectiveness. Mathematical Problems in Engineering, 1-6, 2012.

[44] Evaluation Report, On-Street Car Sharing Pilot Program. San Francisco Municipal Transportation Agency, Sustainable Streets Division-Parking, January 2017.

[45] Belloche, S., On-street Parking Search Time Modelling and Validation with Survey-based Data. Transportation Research Procedia 6, 313 - 324, 2015

[46] Arnott, R. ve Rowse, J., Downtown Parking in Auto-City. Regional Science and Urban Economics, 39(1), 1-14, 2009.

[47] Kozalı, B., Kentiçi Otopark Hizmetlerinde Özel Sektör Katılımının Sürücülerin Park Etme Tercihleri ve Tutumları Üzerine Etkisi. Journal of Life Economics, 1(2), 191-191.

[48] Litman, T., Parking Pricing Implementation Guidelines. Victoria Transport Policy Institute, 2010 .

[49] Gurbetci, K., Demir, A., Çavdar, A., İstanbul'da Sürdürülebilir Ulaşımda Otomobil Öğesi. TRODSA, 4. Ulusal Yol ve Trafik Güvenliği Kongresi, Bil. Kitabı, 201-211, Ankara, 2007. 
[50] Demir, A., Çavdar, A., Yol Kenarı Park Etme Teknolojileri ve İstanbul Uygulaması. OTEKON'08-4. Otomotiv Teknolojileri Kongresi, Bil. Kitabı, 645-653, Bursa, 2008.

[51] Yardım, M.S., Demir, A., İstanbul Otopark Yönetimde Akıllı Ulaştırma Sistemlerinin Kullanımı. İMO, 8. Ulaştırma Kongresi, 2009.

[52] Gurbetci, K., Demir, A., Karaahmet, A., Otopark Uygulamalarında Teknoloji, Çevre ve Emniyet Faktörleri. İlke Yayıncılık, ISBN: 978-605-5961-38-1, 2014.

[53] İnci, E., Bedava Park Etmenin Dayanılmaz Hafifliği. Uluslararası Otopark Politikaları ve Uygulamaları Sempozyumu, Mayıs, İstanbul, 2011.

[54] Kladeftiras, M., Antoniou, C., Simulation-Based Assessment of Double-Parking Impacts on Traffic and Environmental Conditions. Dec 2013.

[55] İSPARK - İstanbul Otopark İşletmeleri Tic. AŞ, Otoparklarla İlgili Bir Kısım Verileri Tedarik Edilmesi, Görüşme Yazışma Usulü, 10.08.2017.

[56] TUİK-Türkiye İstatistik Kurumu, Motorlu Kara Taşıtları, Ocak 2017. Sayı: 24596, 10 Mart 2017, www.tuik.gov.tr, Erișim Tarihi: 06.05.2017.

[57] İsimsiz, İstanbul Nüfusu. http://www.nufusu.com/il/istanbul-nufusu, Erişim Tarihi: 10.07.2017

[58] TÜİK-Türkiye İstatistik Kurumu, Nüfus İstatistikleri. www.tuik.gov.tr, Erişim Tarihi: 06.05.2017.

[59] İstanbul Büyükşehir Belediyesi (IBBB), İstanbul Metropoliten Alanı Kentsel Ulaşım Ana Planı İUAP, Mayis 2011.

[60] Irmscher, I., Otopark Tasarımı, Planlama İlkeleri, Projeler ve Yapılar. YEM Yayın, ISBM: 978605-4793-46-4, s.78, 2015.

[61] EPA, Outline of The Umbrella Organization of The European Parking Industry. European Parking Association, epa-booklet_2015.pdf, Erişim Tarihi: 10.05.2018. 
İstanbul'da Yol Kenarı Parklarda Kullanıcı Alışkanlıklarının İncelenmesi

\section{EKLER}

Tablo E1 - Zaman serisi analiziyle 2013-2017 yılları arasındaki mevsim bazlı ortalama park süresi

\begin{tabular}{|c|c|c|c|c|c|c|c|c|c|c|}
\hline $\mathrm{t}$ & Y1l & Mevsimler & $\begin{array}{l}\text { Ortalama } \\
\text { Park } \\
\text { Süresi, d }\end{array}$ & MA & CMA & St, It & St & Deasonal & $\mathrm{Tt}$ & Forecast \\
\hline 1 & \multirow{4}{*}{2013} & 1 & 110,36 & & & & 0,989 & 111,58 & 113,41 & 112,16 \\
\hline 2 & & 2 & 110,66 & & & & 1,013 & 109,20 & 113,97 & 115,50 \\
\hline 3 & & 3 & 109,94 & 111,99 & 112,74 & 0,98 & 0,990 & 111,09 & 114,53 & 113,34 \\
\hline 4 & & 4 & 117,00 & 113,50 & 114,90 & 1,02 & 1,010 & 115,87 & 115,09 & 116,21 \\
\hline 5 & \multirow{4}{*}{2014} & 1 & 116,39 & 116,30 & 117,38 & 0,99 & 0,989 & 117,69 & 115,65 & 114,38 \\
\hline 6 & & 2 & 121,88 & 118,47 & 118,98 & 1,02 & 1,013 & 120,27 & 116,21 & 117,77 \\
\hline 7 & & 3 & 118,60 & 119,50 & 119,62 & 0,99 & 0,990 & 119,84 & 116,77 & 115,56 \\
\hline 8 & & 4 & 121,13 & 119,74 & 119,46 & 1,01 & 1,010 & 119,96 & 117,33 & 118,47 \\
\hline 9 & \multirow{4}{*}{2015} & 1 & 117,33 & 119,18 & 119,06 & 0,99 & 0,989 & 118,64 & 117,89 & 116,59 \\
\hline 10 & & 2 & 119,67 & 118,95 & 118,89 & 1,01 & 1,013 & 118,09 & 118,45 & 120,04 \\
\hline 11 & & 3 & 117,67 & 118,83 & 119,08 & 0,99 & 0,990 & 118,90 & 119,01 & 117,77 \\
\hline 12 & & 4 & 120,67 & 119,33 & 119,67 & 1,01 & 1,010 & 119,50 & 119,57 & 120,73 \\
\hline 13 & \multirow{4}{*}{2016} & 1 & 119,33 & 120,00 & 120,54 & 0,99 & 0,989 & 120,66 & 120,13 & 118,81 \\
\hline 14 & & 2 & 122,33 & 121,08 & 121,21 & 1,01 & 1,013 & 120,72 & 120,69 & 122,31 \\
\hline 15 & & 3 & 122,00 & 121,33 & 121,54 & 1,00 & 0,990 & 123,28 & 121,25 & 119,99 \\
\hline 16 & & 4 & 121,67 & 121,75 & 121,88 & 1,00 & 1,010 & 120,49 & 121,81 & 123,00 \\
\hline 17 & \multirow{4}{*}{2017} & 1 & 121,00 & 122,00 & 121,84 & 0,99 & 0,989 & 122,35 & 122,37 & 121,02 \\
\hline 18 & & 2 & 123,33 & 121,68 & 121,97 & 1,01 & 1,013 & 121,70 & 122,93 & 124,58 \\
\hline 19 & & 3 & 120,70 & 122,26 & & & 0,990 & 121,97 & 123,49 & 122,21 \\
\hline 20 & & 4 & 124,00 & & & & 1,010 & 122,81 & 124,05 & 125,26 \\
\hline 21 & \multirow{4}{*}{2018} & 1 & & & & & 0,989 & & 124,61 & 123,24 \\
\hline 22 & & 2 & & & & & 1,013 & & 125,17 & 126,85 \\
\hline 23 & & 3 & & & & & 0,990 & & 125,73 & 124,42 \\
\hline 24 & & 4 & & & & & 1,010 & & 126,29 & 127,52 \\
\hline
\end{tabular}




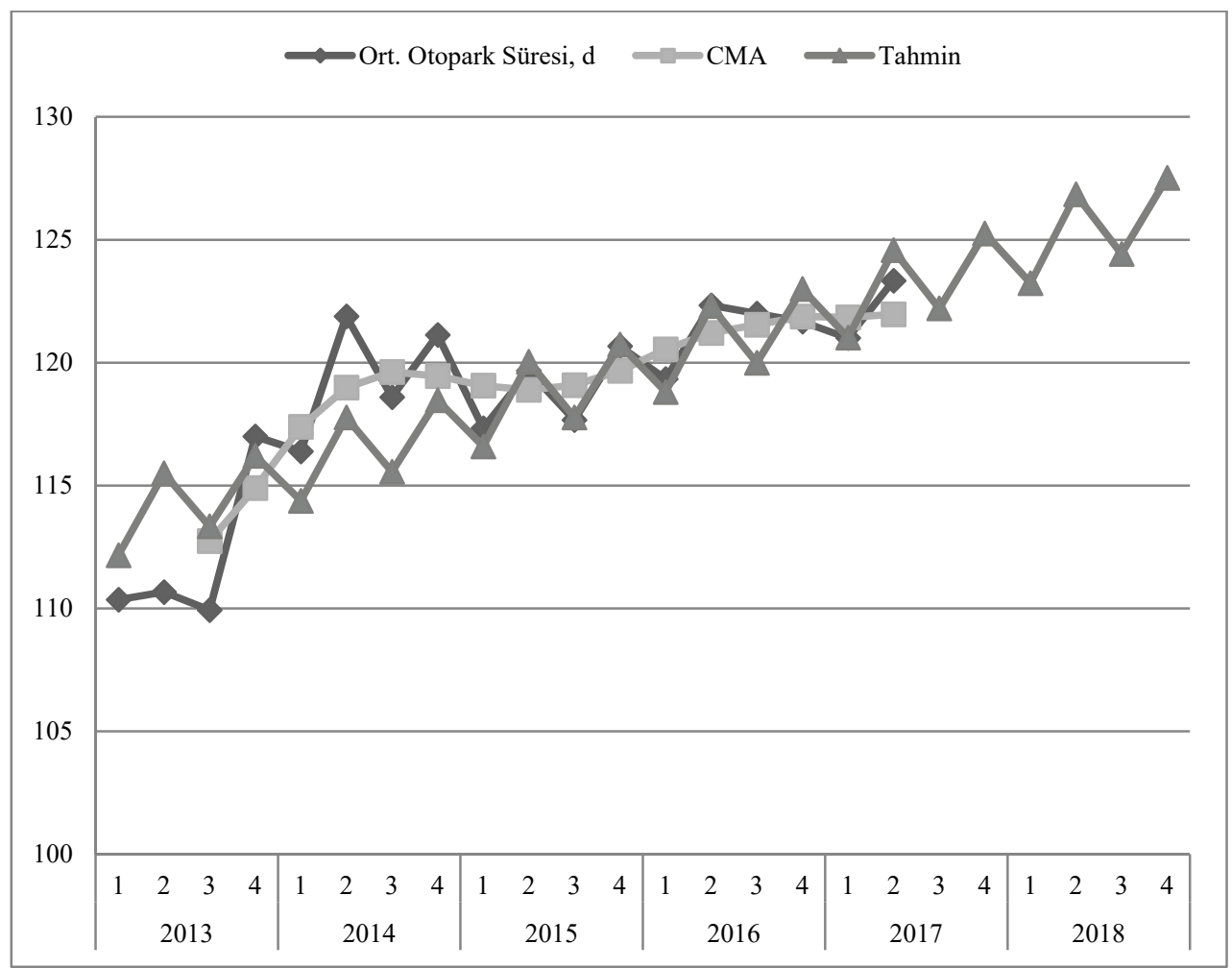

Şekil E1 - Zaman serisi analiziyle 2013-2017 yılları arasındaki mevsim bazlı ortalama park süresi ve 2018 yll tahmini

Tablo E2 - 2010 ve 2017 yllındaki giriş ve günlük ücret tarifeleri ${ }^{1}$

\begin{tabular}{|c|c|c|c|c|c|c|}
\hline & \multicolumn{4}{|c|}{ Giriş Saati ve Ücreti (TL) } & \multicolumn{2}{|c|}{ Tam Gün Ücreti (TL) } \\
\hline & \multicolumn{2}{|c|}{2010} & \multicolumn{2}{|c|}{2017} & \multirow{2}{*}{2010} & \multirow{2}{*}{2017} \\
\hline & $0-2$ & $0-3$ & $0-1$ & $0-2$ & & \\
\hline YKO-2 & $5^{*}$ & & & 7 & 10 & 12 \\
\hline YKO-4 & 4 & 6 & 7 & 8 & 10 & 15 \\
\hline YKO-5 & 5 & 7 & 8 & 10 & 17 & 20 \\
\hline YKO-6 & 5 & 7 & 7 & 8 & 12 & 14 \\
\hline YKO-7 & 4 & 6 & 7 & 8 & 12 & 14 \\
\hline YKO-8 & 3 & 5 & 7 & 8 & 10 & 13 \\
\hline YKO-9 & 4 & 6 & 7 & 8 & 10 & 15 \\
\hline YKO-10 & & 5 & 7 & 8 & 10 & 14 \\
\hline
\end{tabular}

\footnotetext{
${ }^{1}$ Tarife değişikliği 2017'nin başı itibari ile geçerlidir.
} 
Tablo E3 - Zam öncesi ve sonrası otoparklardaki günlük ortalama işlem ve devinim oranları

\begin{tabular}{|c|c|c|c|c|c|c|c|}
\hline \multirow{2}{*}{$\begin{array}{c}\text { Otopark } \\
\text { Lokasyonları }\end{array}$} & \multirow{2}{*}{ Kapasite } & \multicolumn{2}{|c|}{$\begin{array}{c}\text { Tarife } \\
\text { değişikliği, TL }\end{array}$} & \multicolumn{2}{c|}{$\begin{array}{c}\text { Günlük } \\
\text { Ortalama İșlem } \\
\text { Sayısı }\end{array}$} & \multicolumn{2}{|c|}{ Devinim } \\
\cline { 3 - 8 } & & Önce & Sonrası & Öncesi & Sonrası & Önce & Sonra \\
\hline YKO-1 & 10 & $0-1: 6$ & $0-1: 6$ & 95 & 94 & 9,50 & 9,40 \\
\hline YKO-2* & 70 & $0-2: 6$ & $0-2: 7$ & 359 & 369 & 5,13 & 5,27 \\
\hline YKO-3 & 70 & $0-1: 6$ & $0-1: 7$ & 483 & 445 & 6,90 & 6,35 \\
\hline YKO-4 & 16 & $0-1: 6$ & $0-1: 7$ & 77 & 68 & 4,81 & 4,25 \\
\hline YKO-5 & 38 & $0-1: 7$ & $0-1: 8$ & 190 & 148 & 5,00 & 3,89 \\
\hline YKO-6** & 19 & $0-1: 6$ & $0-1: 7$ & 114 & 195 & 6,00 & 10,26 \\
\hline YKO-7 & 60 & $0-1: 7$ & $0-1: 7$ & 411 & 364 & 6,85 & 6,07 \\
\hline YKO-8 & 58 & $0-1: 6$ & $0-1: 7$ & 286 & 280 & 4,93 & 4,83 \\
\hline
\end{tabular}

* Zam öncesi 0-15 d giriș 169 Zam sonrası 0-15 d giriș 188

** Zam öncesi 0-15 d giriş 76 Zam sonrası 0-15 d giriş 137

Tablo E4 - Yol kenarl otoparklarda uygulanmakta olan ücretlendirme ${ }^{l}$

\begin{tabular}{|c|c|c|c|c|}
\hline \multirow{2}{*}{$\begin{array}{c}\text { Park etme süresi, } \\
\text { saat }\end{array}$} & \multirow{2}{*}{$\begin{array}{c}\text { Kullanım } \\
\text { oranı, \% }\end{array}$} & \multicolumn{3}{|c|}{ Bölgelerin ücreti, TL } \\
\cline { 3 - 5 } & Yoğun & Orta yoğun & Düşük yoğun \\
\hline $0-1$ & 35 & 9 & 7 & 4 \\
\hline $0-2$ & 20 & 12 & 9 & 6 \\
\hline $0-4$ & 12 & 16 & 11 & 7 \\
\hline $0-6$ & 5 & 18 & 12,5 & 8 \\
\hline $0-12$ & 5 & 22 & 15 & 10 \\
\hline Aylık abone (Günlük) & 15 & 13 & 9 & 6 \\
\hline
\end{tabular}

Tablo E5 - Yol dışı otoparklarda ortalama otopark birim ücretinin hesaplanması

\begin{tabular}{|l|c|c|c|}
\hline \multicolumn{1}{|c|}{ Otopark } & Kapasite & Devinim & Günlük araç başı ücret, TL \\
\hline YDO-1 & 250 & 0,8 & 12,49 \\
\hline YDO-2 & 275 & 1,1 & 17,96 \\
\hline YDO-3 & 250 & 1,4 & 6,52 \\
\hline YDO-4 & 150 & 1,5 & 5,62 \\
\hline YDO-5 & 250 & 2 & 10,6 \\
\hline YDO-6 & 750 & 2,5 & 15,68 \\
\hline YDO-7 & 240 & 1,2 & 16,02 \\
\hline YDO-8 & 500 & 1,5 & 5,91 \\
\hline YDO-9 & 420 & 2 & 18,17 \\
\hline
\end{tabular}

\footnotetext{
${ }^{1}$ Değerlendirmelerde ortak zemin oluşturabilmek için yol kenarı ücretlendirme süresi 12 saat üzerinden dikkate alınmıştır.
} 
Tablo E6 - Sabit terimli ve terimsiz regrasyon modeli istatistikleri

Sabit terimli model

\begin{tabular}{|c|c|c|c|c|c|c|c|}
\hline Source & SS & $d f$ & MS & \multirow{3}{*}{\multicolumn{2}{|c|}{$\begin{array}{l}\text { Number of obs } \\
F(2,17) \\
\text { Prob }>F\end{array}$}} & $=$ & 20 \\
\hline & & & & & & _ & 17.50 \\
\hline Model & 2163.51467 & 2 & 1081.75734 & & & $=$ & \\
\hline Residual & 1027.20437 & 17 & 60.4237866 & \multicolumn{2}{|c|}{ R-squared } & $=$ & 0.6781 \\
\hline & & & & \multirow{2}{*}{\multicolumn{2}{|c|}{$\begin{array}{l}\text { Adj R-squared } \\
\text { Root MSE }\end{array}$}} & $=$ & 0.6402 \\
\hline Total & 3190.71904 & 19 & 167.932581 & & & $=$ & 7.7733 \\
\hline ücret & Coef. & Std. Err. & $\mathrm{t}$ & $P>|t|$ & {$[95 \% \mathrm{Co}$} & $n f$. & Interval] \\
\hline GSYIH & .0007026 & .0002685 & 2.62 & 0.018 & .000136 & & .001269 \\
\hline sahiplik & -.0838953 & .016513 & -5.08 & 0.000 & -.118734 & & -.049056 \\
\hline _cons & 46.79566 & 12.74339 & 3.67 & 0.002 & 19.9094 & & 73.68186 \\
\hline
\end{tabular}

Sabit terimli model (robust)

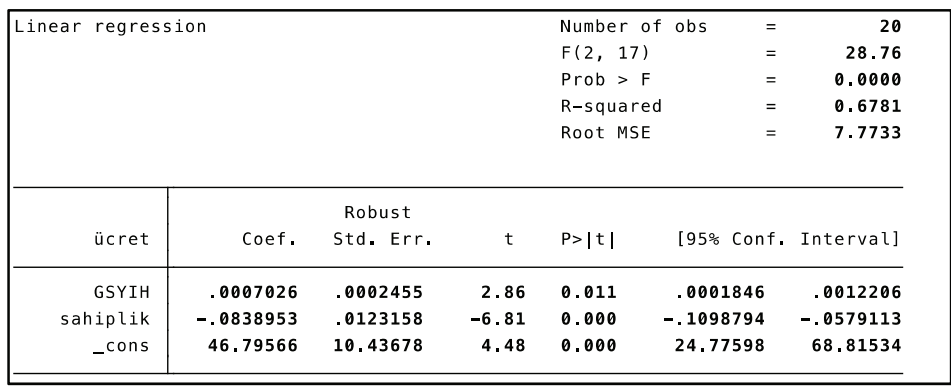

Sabit terimsiz model

\begin{tabular}{|c|c|c|c|c|c|}
\hline Source & SS & $d f$ & MS & \multirow{2}{*}{$\begin{array}{l}\text { Number of obs }= \\
F(2,18)\end{array}$} & 20 \\
\hline & & & & & 115.87 \\
\hline Model & 23714.7276 & 2 & 11857.3638 & Prob > F & 0.0000 \\
\hline Residual & 1842.00096 & 18 & 102.333387 & R-squared & 0.9279 \\
\hline & & & & \multirow{2}{*}{$\begin{array}{l}\text { Adj R-squared } \\
\text { Root MSE }\end{array}$} & 0.9199 \\
\hline Total & 25556.7285 & 20 & 1277,83643 & & 10.116 \\
\hline ücret & Coef. & Std. Err. & $\mathrm{t}$ & $P>|t|$ & Interval] \\
\hline GSYIH & .0014915 & .0002095 & 7.12 & .0010514 & .0019317 \\
\hline sahiplik & -.0436425 & .016072 & -2.72 & $0.014 \quad-.0774084$ & -.0098766 \\
\hline
\end{tabular}

Sabit terımsiz, moael (robust)

\begin{tabular}{|c|c|c|c|c|c|c|c|}
\hline \multicolumn{4}{|c|}{ Linear regression } & \multicolumn{2}{|c|}{$\begin{array}{l}\text { Number of obs } \\
F(2,18) \\
\text { Prob > F } \\
\text { R-squared } \\
\text { Root MSE }\end{array}$} & $\begin{array}{l}= \\
= \\
= \\
= \\
=\end{array}$ & $\begin{array}{r}20 \\
99.60 \\
0.0000 \\
0.9279 \\
10.116\end{array}$ \\
\hline ücret & Coef. & $\begin{array}{l}\text { Robust } \\
\text { Std. Err. }\end{array}$ & $t$ & $P>|t|$ & {$[95 \%$} & Conf. & Interval] \\
\hline $\begin{array}{r}\text { GSYIH } \\
\text { sahiplik }\end{array}$ & $\begin{array}{r}.0014915 \\
-.0436425\end{array}$ & $\begin{array}{r}.000173 \\
.0115657\end{array}$ & $\begin{array}{r}8.62 \\
-3.77\end{array}$ & $\begin{array}{l}0.000 \\
0.001\end{array}$ & $\begin{array}{r}.00 \\
-.067\end{array}$ & $\begin{array}{l}1128 \\
9411\end{array}$ & $\begin{array}{r}.001855 \\
-.0193439\end{array}$ \\
\hline
\end{tabular}

\section{Korelasyon tablosu}

\begin{tabular}{|r|rrr|}
\hline & ücret & GSYIH sahiplik \\
\hline ücret I & $\mathbf{1 . 0 0 0 0}$ & & \\
GSYIH & $\mathbf{0 . 4 3 5 0}$ & $\mathbf{1 . 0 0 0 0}$ & \\
sahiplik & $\mathbf{- 0 . 7 4 0 5}$ & $\mathbf{- 0 . 1 0 3 7}$ & $\mathbf{1 . 0 0 0 0}$ \\
& & & \\
\hline
\end{tabular}


